NBER WORKING PAPER SERIES

\title{
DESIGNING CLIMATE MITIGATION POLICY
}

\author{
Joseph E. Aldy \\ Alan J. Krupnick \\ Richard G. Newell \\ Ian W.H. Parry \\ William A. Pizer \\ Working Paper 15022 \\ http://www.nber.org/papers/w15022
NATIONAL BUREAU OF ECONOMIC RESEARCH
1050 Massachusetts Avenue
Cambridge, MA 02138
June 2009

The authors are grateful to Carolyn Fischer, Roger Gordon, Charles Kolstad, and Brent Sohngen for helpful comments on an earlier draft. The views expressed herein are those of the author(s) and do not necessarily reflect the views of the National Bureau of Economic Research.

NBER working papers are circulated for discussion and comment purposes. They have not been peerreviewed or been subject to the review by the NBER Board of Directors that accompanies official NBER publications.

(C) 2009 by Joseph E. Aldy, Alan J. Krupnick, Richard G. Newell, Ian W.H. Parry, and William A. Pizer. All rights reserved. Short sections of text, not to exceed two paragraphs, may be quoted without explicit permission provided that full credit, including $(\subset$ notice, is given to the source. 
Designing Climate Mitigation Policy

Joseph E. Aldy, Alan J. Krupnick, Richard G. Newell, Ian W.H. Parry, and William A. Pizer

NBER Working Paper No. 15022

June 2009

JEL No. H23,Q48,Q54

\section{$\underline{\text { ABSTRACT }}$}

This paper provides an exhaustive review of critical issues in the design of climate mitigation policy by pulling together key findings and controversies from diverse literatures on mitigation costs, damage valuation, policy instrument choice, technological innovation, and international climate policy. We begin with the broadest issue of how high assessments suggest the near and medium term price on greenhouse gases would need to be, both under cost-effective stabilization of global climate and under net benefit maximization or Pigouvian emissions pricing. The remainder of the paper focuses on the appropriate scope of regulation, issues in policy instrument choice, complementary technology policy, and international policy architectures.

Joseph E. Aldy

Resources for the Future

1616 P Street, NW

Washington, DC 20036

aldy@rff.org

Alan J. Krupnick

Resources for the Future

1616 P Street, NW

Washington, DC 20036

krupnick@rff.org

Richard G. Newell

Nicholas School of the Environment

Duke University

Box 90227

Durham, NC 27708

and NBER

richard.newell@duke.edu
Ian W.H. Parry

Resources for the Future

1616 P Street, NW

Washington, DC 20036

parry@rff.org

William A. Pizer

Resources for the Future

1616 P Street, NW

Washington, DC 20036

billy.pizer@gmail.com 


\title{
Designing Climate Mitigation Policy
}

\author{
Joseph E. Aldy, Alan J. Krupnick, Richard G. Newell, \\ Ian W.H. Parry, and William A. Pizer*
}

\section{Introduction}

Global warming is one of the most critical, and also most daunting, challenges facing policymakers in the twenty-first century. Assessing a globally efficient time path for pricing or controlling greenhouse gas (GHG) emissions is difficult enough, with huge scientific uncertainties, disagreement over the ultimate goals of climate policy, and disagreement over which countries should bear most responsibility for emissions reductions. On top of this, domestic policy design is inherently difficult because of multiple, and sometimes conflicting, criteria for policy evaluation. And at an international level, there are multiple approaches to coordinating emissions control agreements. What might a rational policy response for such an enormously complex problem look like?

This paper attempts to provide some broad answers to this question, and pinpoint the main sources of controversy, by pulling together key findings from diverse literatures on mitigation costs, damage valuation, policy instrument choice, technological innovation, and international climate policy. Our aim is to do this in a highly succinct fashion, so the nonspecialist can quickly get up to speed on the key issues without getting drawn into the details.

We begin with the broadest issue of how much action to price or control GHGs is warranted in the near and longer term at a global level. There are two distinct approaches to this question. The cost-effectiveness approach acknowledges that policymakers typically have some ultimate target for limiting the amount of projected climate change or atmospheric GHG accumulations, and the question is what policy trajectory might achieve alternative goals at minimum economic cost while accounting for practical constraints, such as incomplete

\footnotetext{
* Joseph E. Aldy is now on leave from RFF, serving as special assistant to the president on energy and the environment; his work on this paper was completed while he was a full-time fellow at RFF. Alan J. Krupnick is a senior fellow at RFF. Richard G. Newell is a professor at the Nicholas School of the Environment, Duke University, Durham, NC. Ian W.H. Parry is a senior fellow at RFF. William A. Pizer is the deputy assistant secretary for environment and energy at the Treasury Department; his work on this paper was completed while he was a full-time senior fellow at RFF.
} 
international coordination. The other approach is to weigh the benefits and costs of slowing climate change, which introduces highly contentious issues in damage valuation, dealing with extreme climate risks, and intergenerational discounting.

The second part of the paper deals with issues in the implementation of climate policy. At a domestic (U.S.) level these include a comparison of alternative emissions control instruments and how they could be designed to simultaneously promote administrative ease and minimize efficiency costs in the presence of other policy distortions, abatement cost uncertainty, and possible distributional constraints. We discuss the extent to which additional policies are warranted to promote the development and deployment of emissions-saving technologies, and we briefly summarize emerging literature on alternative international policy architectures. A final section discusses key areas for future research.

\section{Policy Stringency}

\subsection{Emissions Pricing to Stabilize Global Climate}

The cost-effectiveness approach to global climate policy uses models of the economic and climate systems (known as integrated assessment models) to estimate the emissions price trajectory that minimizes the discounted worldwide costs of emissions abatement, subject to a climate stabilization target, and possibly other, practical constraints like delaying developing country participation. These models range from bottom-up engineering-economic models with considerable detail on adoption and use of energy technologies, to computable general equilibrium models with a more aggregated and continuous structure that better represents demand responses, capital dynamics, and factor substitution. Many models are hybrids containing substantial technological detail in the energy sectors and more aggregate representation in others. Typically the suite of existing and emerging technologies is taken as given, though some models capture induced innovation through learning-by-doing, and a few have incorporated R\&D-based technological change (e.g., Goulder and Matthai 2000, Popp 2006).

A variety choice of model structure choices affect cost estimates, including decisions about foresight, trade sensitivities, capital mobility, and sectoral disaggregation, which influence opportunities for cost-effective abatement across time and space. However, the choice of model structure is generally less important than assumptions about future baseline data and technology options. Future mitigation costs are highly sensitive to business-as-usual (BAU) emissions, which depend on future population and Gross Domestic Product (GDP) growth, the energy 
intensity of GDP, and the fuel mix. They also depend on the future availability and cost of emissions-saving technologies like nuclear and renewable power, carbon capture and storage, and alternative transportation fuels. Considerable uncertainty surrounds all of these factors.

Given the difficulty of judging which models give the most reliable predictions, we discuss a representative sample of results, beginning with studies that assume emissions reductions are efficiently allocated across countries and time and use the least expensive technological options. This is known as "where, when, and how" flexibility. These studies, summarized in Table 1, are from the U.S. Climate Change Science Program (CCSP, Product 2.1A), based on results from the IGSM, MERGE, and MiniCAM models (see Clarke 2007 et al. for model details), and from the Stanford Energy Modeling Forum's EMF-21 study (reported in de la Chesnaye and Weyant 2006), which draws on results from 16 energy-economic model teams.

\subsubsection{Reference Scenarios}

Global $\mathrm{CO}_{2}$ emissions from fossil fuels have grown from about 2 billion (metric) tons in 1900 to current levels of about 30 billion tons and, in the absence of mitigation policy, are projected to at least double from 2000 levels by the end of the century (Table 1). The huge bulk of the projected future emissions growth is in non-Annex 1 (nonindustrial) countries-emissions from these countries overtake those from Annex 1 (industrial) countries in the models by around 2020 to $2030 .{ }^{1}$ These rising emissions trends reflect growing energy demand from population and real income growth that will outweigh energy- and emissions-saving technological changetraditional fossil fuels still account for around three-quarters of global primary energy consumption by 2100 (Clarke et al. 2007, Table TS1). ${ }^{2}$

About 45 percent of $\mathrm{CO}_{2}$ releases are immediately absorbed by the upper oceans and terrestrial biosphere, while the remainder enters the atmosphere and is removed by the ocean and terrestrial sinks only very gradually (IPCC 2007). The longer-term rate of removal of $\mathrm{CO}_{2}$ from

\footnotetext{
${ }^{1}$ The 1990 U.N. Framework Convention on Climate Change (UNFCCC) grouped countries into either Annex 1 or non-Annex 1 according to their per capita income at that time. Only Annex 1 countries agreed to reduce emissions under the 1997 Kyoto Protocol.

${ }^{2}$ Land-use changes currently contribute about an additional 5.5 billion tons of $\mathrm{CO}_{2}$ releases (primarily through deforestation in developing countries for agriculture and timber), though these sources are projected to grow at a much slower pace than fossil fuel emissions (IPCC 2007). Land-use $\mathrm{CO}_{2}$ emissions are not priced in the models in Table 1.
} 
the atmosphere is around 1 percent a year (i.e., $\mathrm{CO}_{2}$ has an expected atmospheric residence time of about a century or more), and even this very gradual decay rate might decline as oceans become more saturated with $\mathrm{CO}_{2}$. Stabilizing atmospheric $\mathrm{CO}_{2}$ concentrations over the very long term essentially requires elimination of fossil fuel and other GHG emissions.

Atmospheric $\mathrm{CO}_{2}$ concentrations increased from preindustrial levels of about 280 parts per million (ppm) to $384 \mathrm{ppm}$ in 2007 and are projected to rise to around 700-900 ppm by 2100 (Table 1). Accounting for non- $\mathrm{CO}_{2} \mathrm{GHGs}$, such as methane and nitrous oxides from agriculture and other sources, and expressing them on a lifetime warming equivalent basis increases the projected gap between future atmospheric GHG concentrations and preindustrial levels by around 25-30 percent (Clarke et al. 2007, Table TS1). Total GHG concentrations in $\mathrm{CO}_{2}$ equivalents are projected to reach $550 \mathrm{ppm}$ (i.e., roughly double preindustrial levels) by around midcentury.

To date, globally averaged surface temperature is estimated to have risen by $0.74^{\circ} \mathrm{C}$ between 1906 and 2006, with most of this warming due to rising atmospheric GHG concentrations, as opposed to other factors like changes in solar radiation, volcanic activity, and urban heat absorption (IPCC 2007). Figure 1, from IPCC (2007), shows projected steady state warming levels associated with different stabilization levels for atmospheric GHG concentrations (the climate system takes several decades to fully adjust to changing concentration levels due to heat diffusion processes in the oceans). If atmospheric GHG concentrations were stabilized at $550 \mathrm{ppm}$, the likely global temperature increase above preindustrial levels is $2.0-4.5^{\circ} \mathrm{C}$, with a best estimate of $3.0^{\circ} \mathrm{C}$, while if $\mathrm{CO}_{2}$ equivalent concentrations were stabilized at $650 \mathrm{ppm}$, mean projected warming would be $3.5^{\circ} \mathrm{C}$, with a likely range of $2.5-5.5^{\circ} \mathrm{C}$. The "likely ranges" refer to a roughly 66 percent confidence interval, based on sensitivity analysis from scientific models. The fundamental concern is that warming might greatly exceed these levels due to poorly understood feedbacks not represented in these models, such as heat-induced releases of methane stored under the oceans and in the permafrost (Harvey and Zhen 1995).

\subsubsection{Least-Cost Pricing}

Most political debate has focused on climate stabilization targets that are approximately consistent with limiting atmospheric $\mathrm{CO}_{2}$ concentrations to either 450 or $550 \mathrm{ppm}$ (with other GHGs included, the corresponding $\mathrm{CO}_{2}$ equivalent concentrations would be somewhat less or somewhat greater than double preindustrial levels). The studies in Table 1 examine globally cost-

effective emissions pricing trajectories that are approximately consistent with these goals, that is, 
marginal abatement costs are equated across all emissions sources (including non- $\mathrm{CO}_{2} \mathrm{GHGs}$ ), across countries, and across different periods of time. ${ }^{3}$

Across the models and stabilization scenarios in Table $1, \mathrm{CO}_{2}$ emissions prices rise steadily (beginning around 2012) at approximately 5 percent, which is roughly equal to the consumer discount rate plus the atmospheric $\mathrm{CO}_{2}$ decay rate (Peck and Wan 1996). However, one striking feature in Table 1 is the considerable variation across models within a stabilization scenario, reflecting different assumptions about future BAU emissions growth and future availability of carbon-saving technologies. The other striking feature is the dramatic differences between the 550 and 450 ppm $\mathrm{CO}_{2}$ stabilization targets. In the $550 \mathrm{ppm}$ case, $\mathrm{CO}_{2}$ prices are about \$5-30 and \$10-100 per ton in 2025 and 2050, respectively, with emissions 15-40 percent and 15-55 percent above 2000 levels at these dates, respectively. In the $450 \mathrm{ppm}$ case, $\mathrm{CO}_{2}$ prices are about 3-14 times those in the $550 \mathrm{ppm}$ case to midcentury, while emissions are $0-15$ percent and 35-50 percent below 2000 levels in 2025 and 2050, respectively. ${ }^{4}$

Although GDP losses may be an unreliable proxy for efficiency losses when climate policies compound preexisting policy distortions (see below), we discuss them here as they are the least common denominator reported by the modeling groups. ${ }^{5}$ Under the $550 \mathrm{ppm} \mathrm{CO}_{2}$ target, most models project global GDP losses (from reducing both $\mathrm{CO}_{2}$ and non- $\mathrm{CO}_{2} \mathrm{GHGs}$ ) of less than 1 percent out to 2050, though some models suggest GDP losses could reach 2-3 percent by this date. In present value terms these GDP losses amount to about \$0.4-12 trillion out to 2050 when applied to a world GDP that is $\$ 60$ trillion and growing (Newell 2008, 12). Under the 450 ppm $\mathrm{CO}_{2}$ target, cumulative GDP losses are about 1.0-2.5 percent and 1.5-5.5 percent in 2025 and 2050, respectively, or about \$8-43 trillion in present value from 2010 to 2050.

Under both the 450 and 550 ppm stabilization scenarios the energy system is transformed over the next century (though at very different rates) through energy conservation, improved energy efficiency, and particularly through reductions in the carbon intensity of energy use. Most of the emissions reductions in the first two to three decades occur in the power sector, largely

\footnotetext{
${ }^{3} \mathrm{We}$ focus on $\mathrm{CO}_{2}$ concentrations, given that models use different conventions for measuring $\mathrm{CO}_{2}$ equivalents for other GHGs.

${ }^{4}$ Some analysts express prices per ton of carbon rather than $\mathrm{CO}_{2}$. To convert to $\$$ per ton of carbon, multiply by the ratio of molecular weights, $44 / 12=3.67$.

${ }^{5}$ GDP losses may also understate efficiency losses because they include changes in regional investment, which often increase in the near term in climate policy simulations.
} 
through the progressive replacement of traditional coal plants by coal with carbon capture and storage, natural gas, nuclear, and renewables (wind, solar, and biomass), though the projected fuel mix is highly sensitive to assumptions about the relative costs and availability of future technologies (e.g., it is not clear to what extent practical and safety obstacles will constrain nuclear power and whether carbon capture and storage technologies will prove viable). ${ }^{6}$

As for U.S. $\mathrm{CO}_{2}$ emissions, in the reference case they increase by about 30-100 percent above 2000 levels (of approximately 6 billion tons) by midcentury (Table 1). Under the 550 ppm target, emissions initially rise, fall to roughly 2000 levels by 2050, and fall rapidly thereafter. Under the $450 \mathrm{ppm}$ target, U.S. emissions are rapidly reduced to roughly half 2000 levels by 2050. U.S.-specific GDP losses are not reported in the studies in Table 1, but allocating a quarter of the global cost to the United States (based on its share in global GDP) implies a present value cost to the United States through midcentury of about \$0.1-3 trillion (0-1 percent of the present value of GDP) for the 550 ppm target and \$2-11 trillion (1-3 percent of present value GDP) for the 450 ppm target. ${ }^{7}$

\subsubsection{Deviations from Least-Cost Pricing}

Aside from the uncertainty surrounding modeling assumptions, a key problem with the studies in Table 1 is that they assume globally efficient abatement policies. More likely, particularly given the "common but differentiated responsibilities" recognized in the UNFCCC, participation in global mitigation efforts among major emitters in developing countries will be delayed, causing marginal abatement costs to differ across regions. For a given climate stabilization scenario, to what extent does this affect worldwide abatement costs and appropriate policies in developed countries like the United States?

Edmonds et al. (2008) explore these issues by assuming Annex 1 countries agree to impose a harmonized emissions price starting in 2012, China joins the agreement at a later date, and other countries join whenever their per capita income reaches that of China at the time of

\footnotetext{
${ }^{6}$ In part, the transition away from coal reflects the disproportionately large impact of emissions pricing on coal prices. A $\$ 10$ price per ton of $\mathrm{CO}_{2}$ in the United States would increase 2007 coal prices to utilities by about 60 percent, wellhead natural gas prices by 9 percent, retail electricity and crude oil prices by 7 percent each, and gasoline prices by 3 percent (from Clarke et al. 2007, Table TS5, and www.eia.gov).

${ }^{7}$ U.S.-specific models project emissions price ranges that are broadly consistent with those in Table 1. For example, analyses by Paltsev et al. (2007), EPA (2008), EIA (2008a), and CRA International (2008) project emissions prices of around $\$ 40-90$ per ton of $\mathrm{CO}_{2}$ in 2025 for climate legislation that would reduce U.S. $\mathrm{CO}_{2}$ emissions by about 20 percent below 2000 levels by that date.
} 
China's accession. In one scenario, they assume new entrants immediately face the prevailing Annex 1 emissions price, while in another the emissions price for late entrants converges gradually over time to the Annex 1 price. The analysis accounts for emissions leakage, that is, the increase in emissions in nonparticipating countries due to the flight of energy-intensive firms from participating countries, and also the increased use of fuels in nonparticipating countries as decreased demand from participating countries puts downward pressure on world fuel prices.

Under the 550 ppm target, even if China joins between 2020 and 2035, the implications for Annex 1 policies can be significant but are not that striking. Compared with the globally efficient policy (with a globally harmonized price at all times), near-term Annex 1 emissions prices rise from between a few percent and 100 percent under the different scenarios, and discounted global abatement costs are higher by 10-70 percent. However, under the $450 \mathrm{ppm}$ target, essentially all of the foregone earlier reductions in non-Annex 1 countries must be offset by additional early reduction in Annex 1 countries (rather than more global abatement later in the century). This can imply dramatically higher near-term Annex 1 emissions prices, especially with longer delay and lower initial prices for late entrants. Under these scenarios, discounted global abatement costs are about 30-400 percent higher than under globally efficient pricing, and near- and medium-term emissions prices can be an order of magnitude larger if China's accession is delayed until 2035.

A further key point from Edmonds et al. (2008) is the potentially large shift in the global incidence of abatement costs, underlying the disincentives for early developing country participation. In the globally efficient policy, developing countries bear about 70 percent of discounted abatement costs out to 2100 - gross of any compensation payments — while they bear “only" 17-34 percent of global abatement costs when China's accession occurs in 2035 and new entrants face lower starting prices.

Finally, insofar as possible, pricing non-CO2 GHGs is also important. According to modeling results in de la Chesnaye and Weyant (2006), GDP costs are 20-50 percent larger when only $\mathrm{CO} 2$, as opposed to all, GHGs are priced, for the same overall limit on atmospheric GHG concentrations. This reflects opportunities for large-scale, low-cost options for non-CO2 abatement in the first half of this century, though practical difficulties in pricing other GHGs are not factored into the models (see below).

\subsubsection{Summary}

There is a large difference in the appropriate starting prices for GHG emissions, depending on whether the ultimate objective is to limit atmospheric $\mathrm{CO}_{2}$ concentrations to 450 or 
$550 \mathrm{ppm}$ - targets that are approximately consistent with keeping the eventual, mean projected warming above today's temperatures to $1.5^{\circ} \mathrm{C}$ or $2.5^{\circ} \mathrm{C}$, respectively (assuming non- $\mathrm{CO}_{2} \mathrm{GHGs}$ are also priced). The $450 \mathrm{ppm}$ target implies emissions prices would need to reach around $\$ 40$ 90 per ton of $\mathrm{CO}_{2}$ by 2025 , while the $550 \mathrm{ppm}$ target implies prices would need to rise to $\$ 3-25$ by that date. Securing early and widespread participation in an international emissions control regime can also be critical for containing costs under the $450 \mathrm{ppm}$ target, while under the 550 ppm target there is greater scope for offsetting the effect of delayed participation through greater emissions reductions in the latter half of the century. Given the considerable difference in GDP losses at stake between the two targets ( $\$ 8-43$ trillion in present value under cost-effective pricing out to 2050 compared with $\$ 0.4-12$ trillion), it is important to carefully assess what starting prices might be consistent, from an efficiency perspective, with the benefits of slowing climate change.

\subsection{Welfare-Maximizing Emissions Pricing}

\subsubsection{Marginal Damage Estimates}

Estimates of the marginal damages from emissions begin with a point estimate of contemporaneous damages from a given amount of future warming, usually occurring around 2100. At first glance, total damage estimates from multiple studies appear to be in roughly the same ballpark for a given amount of warming. According to the representative estimates shown in Figure 2, world damages are in the range of about 1-2 percent of GDP for a warming of $2.5^{\circ} \mathrm{C}$ above preindustrial levels, though some estimates are close to zero or even negative, particularly for market impacts (the prospects for negative costs diminishes with greater warming). For warming of about $4.0^{\circ} \mathrm{C}$, damages are typically in the order of 2-4 percent of world GDP. However, there are huge inconsistencies across these studies as they reach dramatically different conclusions about the size of market and nonmarket damage categories and expected catastrophic risks (Figure 2).

Very few studies attempt to value the damages from more extreme warming scenarios, given so little is known about the physical impacts of large temperature changes. Two exceptions are Nordhaus and Boyer (2000) and Stern (2007), who put total damages at 10.2 percent and 11.3 percent of world GDP for warming of $6.0^{\circ} \mathrm{C}$ and $7.4{ }^{\circ} \mathrm{C}$, respectively, though these figures are largely based on extrapolations and subjective judgment. Again, there is little consistency across the estimates. In Nordhaus and Boyer (2000) catastrophic risks and market damages account for about 60 and 40 percent of expected total damages, respectively, with nonmarket 
impacts roughly washing out, while in the Stern estimate nonmarket impacts account for about half of damages.

Marginal damage estimates are inferred by using assumptions about emissions/concentration relationships, climate adjustment and sensitivity, climate damages (inferred from a point estimate by using functional form assumptions), and discount rates. Tol (2009) conducts several meta-analyses of marginal damage estimates, reporting a median of \$420 per ton of $\mathrm{CO} 2$, and a mean of \$28-35 per ton across the different analyses (studies within a meta-analysis are not independent, however, often drawing from the same sources and from each other). Although individual estimates are highly divergent, most are on the low side. Especially striking is the difference between Stern (2007) at $\$ 85$ and Nordhaus (2008) at $\$ 8$ per ton of $\mathrm{CO} 2$ - a difference largely dependent on discount rate assumptions (see below). Most estimates of near-term Pigouvian taxes (i.e., marginal damages at the optimized level of emissions) are similar to marginal damage estimates at uncontrolled (i.e. existing) emissions levels, though Stern (2007) pp. 344 is an exception. ${ }^{8}$

There is some consensus that marginal damages grow over time at around 2-3 percent a year (approximately the rate of growth in output potentially affected by climate change), or at about half the rate as under cost-effective emissions pricing associated with an atmospheric concentration target. Marginal damages increase with the extent of warming over time (suggesting a faster rate of increase), but an offsetting factor is that warming is a concave (logarithmic) function of atmospheric GHG concentrations. Although atmospheric CO2 concentrations ultimately reach $650 \mathrm{ppm}$ in the twenty-second century in Nordhaus's (2008) optimal policy, imposing a constraint that $\mathrm{CO} 2$ concentrations cannot exceed 550 ppm has only a modest effect on the emissions price trajectory out to 2050. In short, optimal near- and mediumterm emissions prices in Nordhaus (2008) are in the same ballpark with those for cost-effective stabilization of CO2 concentrations at 550 ppm, while starting prices in Stern (2007) are broadly consistent with cost-effective prices to stabilize $\mathrm{CO} 2$ concentrations at $450 \mathrm{ppm}$ or lower.

\footnotetext{
${ }^{8}$ Some of the differences in marginal damage estimates in the literature also reflect different assumptions about the year for which emissions are being priced, the extent of future warming from GHG accumulations, and reporting in different year's dollars.
} 


\subsubsection{Controversies in Marginal Damage Assessment}

Differences in marginal damage estimate in the literature are largely explained by fundamentally different approaches to discounting rather than differences in total damages from a given amount of warming (Nordhaus 2007). However, the valuation of catastrophic and noncatastrophic damages is also highly contentious. We take each of these issues in turn.

Discounting. Stern (2007) uses a discount rate on future consumption of 1.4 percent. This is based on the prescriptive approach, which decomposes the discount rate on the consumption of future generations into the pure rate of time preference and the product of the growth rate in consumption (assumed to be 1.3 percent in that study) and the elasticity of marginal utility with respect to consumption (assumed to be 1). Choosing a value for the pure rate of time preference, the rate at which the utility of future generations is discounted just because they are in the future, is viewed as a strictly ethical judgment. And ethical neutrality, in this approach, essentially requires setting the pure rate of time preference essentially equal to zero ${ }^{9}$ (the fact that individuals over their lifetime prefer early utility to later utility is not viewed as an argument for discounting one generation over another). Discriminating against people just because they are in the future is viewed as being akin to discriminating against people in the present generation just because they live in different countries (Heal 2009). ${ }^{10}$

In contrast, Nordhaus (2008) uses a consumption discount rate of about 5 percent. This is based on the descriptive approach, which argues that we can do no better than using observed market rates as these reveal preferences, as best we understand them, and reflect the return earned by a broad range of private and public investments - the opportunity cost against which

\footnotetext{
${ }^{9}$ Note that Stern (2007) assume a pure rate of time preference of 0.1 percent (rather than zero) based on the possibility that the human race may not survive.

${ }^{10}$ Besides ethical arguments, Sterner and Persson (2008) argue for discounting the nonmarket impacts of climate change (e.g., ecosystem loss) at below market rates. This is because the value of nonmarket goods (which are essentially fixed in supply) rises over time relative to the value of market goods (for which supply increases along with demand), assuming market and nonmarket goods are imperfect substitutes for one another. However, gauging the substitution elasticity between market and nonmarket goods, and how this elasticity may change over coming decades, is especially challenging. In addition, changing relative prices over time and discounting are distinct conceptual issues that are ideally treated separately.
} 
other, even intergenerational, investments ought to be measured. ${ }^{11}$ Proponents of the descriptive approach view discounting at market rates as essential for meaningful, consistent policy analysis and to avoid perverse implications in other policy contexts (e.g., Nordhaus 2007).

Catastrophic Risks. The second critical source of controversy in marginal damage assessment is the treatment of extreme, catastrophic risk. Although Nordhaus and Boyer (2000) and Stern (2007) include catastrophic risks in their damage assessments, the numbers were best viewed as highly speculative placeholders until more sophisticated analyses became available. Nordhaus and Boyer (2000) put the annual costs from catastrophic risks at 1.0 percent and 6.9 percent of world GDP for warming levels of $2.5^{\circ} \mathrm{C}$ and $6.0^{\circ} \mathrm{C}$, respectively. These figures are based on assumptions that catastrophic climate change would permanently wipe out 25 percent of world GDP with a 1.0 percent and 6.9 percent probability at these warming levels, respectively, where these probabilities are based on a (subjective) expert elicitation survey. In his central case, Stern (2007) assumes the chance of catastrophic climate change is zero up to a warming of about $5^{\circ} \mathrm{C}$, beyond which the annualized risk of regional GDP losses of 5-20 percent rises by about 10 percent for each additional $1^{\circ} \mathrm{C}$ of warming.

Weitzman (2009a) takes a radically different perspective, contending that smallprobability, extreme events may render Pigouvian tax assessment futile. In particular, if the probability of increasingly catastrophic outcomes falls more slowly than marginal utility rises in those outcomes (with diminished consumption), then the certainty-equivalent marginal damage from current emissions becomes infinite. These conditions apply if the probability distribution for climate sensitivity is a fat-tailed $t$-distribution (i.e., approaches zero at a less than exponential rate) and utility is a power function of consumption. Although marginal utility is probably not unbounded, Weitzman (2009a) shows that with probabilities of a $20^{\circ} \mathrm{C}$ temperature change inferred from IPCC (2007), and assuming this temperature change would lower world consumption to 1 percent of its current level, expected catastrophic damages could easily dwarf

\footnotetext{
${ }^{11}$ Although there are many market rates, from the long-term pretax real return to equities (about 7 percent) to the after-tax return to government bonds (about 2 percent), much of this variation depends on whether we are looking for a rate to discount investments or intertemporal consumption choices. Converting all values into their consumption equivalents, and discounting at the consumption rate of interest, narrows the possible range of choice (see, e.g., Lind 1982). In fact McGratten and Prescott (2003) suggest that the divergence in effective rates of return is actually small, with an average real debt return during peacetime over the last century of almost 4 percent and the average equity return somewhat under 5 percent.
} 
noncatastrophic damage estimates. This conclusion applies even if this warming occurs more than a century from now and conventional discount rates are applied. ${ }^{12}$

There are several possible responses to the Weitzman critique. One is that there is disagreement as to whether the probability distribution for climate sensitivity is fat- or thintailed. If the distribution is thin-tailed, Newbold and Daigneault (2008) and Pindyck (2008) find that the willingness to pay to avoid the low-probability of extreme global warming is well under 3 percent of consumption (rather than infinitely large), under most parameter values.

A second response is that setting a more modest Pigouvian tax now does not preclude the possibility of a midcourse policy correction, involving a rapid phasedown in global emissions if future observations and evidence suggest that we are heading toward a global catastrophe (e.g., Yohe and Tol 2009). This argument critically assumes that policymakers can avoid a catastrophic outcome in the future through limiting future additions to atmospheric accumulations - it breaks down if avoiding a catastrophe in the future would require reversing previous atmospheric accumulations.

A third response is that a costly, rapid stabilization of atmospheric GHG concentrations is a highly inefficient way to address the very small probability of catastrophic outcomes if a portfolio of last-resort technologies could be successfully developed and deployed, if needed, to prevent runaway warming. These include "air capture" technologies for removing GHGs out of the atmosphere and "geoengineering" technologies for modifying the global climate. ${ }^{13}$ Moreover, R\&D efforts can be led by one or several countries, avoiding the challenges endemic in organizing a rapid emissions phasedown among a large number of emitters with widely differing interests. Nonetheless, analysts are divided on the case for public support for R\&D into lastresort technologies, which is virtually nonexistent at present. One objection is the possibility that relying on last-resort technologies could undermine efforts to initiate emissions mitigation

\footnotetext{
12 The IPCC report provides probability distributions from 22 scientific studies. Combining these distributions, Weitzman (2009a) suggests that there is a 5 percent and 1 percent probability that eventual warming from a doubling of $\mathrm{CO}_{2}$ equivalent concentrations will exceed $4.5^{\circ} \mathrm{C}$ and $7.0^{\circ} \mathrm{C}$ respectively. However, making an (extremely crude) adjustment for the possibility of feedback effects (e.g., heat-induced releases of sequestered methane from the permafrost), he infers a distribution where the probability that eventual temperature change exceeds $10^{\circ} \mathrm{C}$ and $20^{\circ} \mathrm{C}$ is 5 percent and 1 percent, respectively.

${ }^{13}$ Besides rapid reforestation programs, air capture might involve bringing air into contact with a sorbent material that binds chemically with $\mathrm{CO}_{2}$ and extraction of the $\mathrm{CO}_{2}$ from the sorbent for underground, or other, disposal. Geoengineering technologies include, for example, deflection of incoming solar radiation through shooting particles into the stratosphere or blowing oceanic water vapor to increase the cover of reflective, bright clouds.
} 
programs - a type of moral hazard. The other is that geoengineering (though not air capture) technologies could have extreme downside risks (e.g., from overcooling the planet or radically altering precipitation patterns) that may be difficult to evaluate prior to widespread deployment. Whether effective institutions could be developed to prevent unilateral deployment of climate modification technologies prior to rigorous assessment of their risks is also unclear (e.g., Barrett 2008; Victor 2008).

In short, the implications of extreme catastrophic risks for emissions pricing remain highly unsettled in the literature. So long as there is still some positive likelihood that the climate sensitivity function is fat-tailed - a possibility that Weitzman (2009b) argues cannot be ruled out - then catastrophic risks can still swamp noncatastrophic impacts, depending on the shape of the utility function. Conceivably, midcourse corrections in emissions pricing may come too late to prevent a catastrophe, given that atmospheric GHG accumulations are irreversible, that it may take several decades for the full warming impacts of higher concentrations to be realized, and given the possibility of tipping points in the climate system. And the future viability of last-resort technologies is highly uncertain at present. All of these issues - the nature and extent of damages from extreme warming, the possibility of future, midcourse corrections for near- and mediumterm emissions pricing, and the efficient balance between mitigation and investment in last-resort technologies - are in urgent need of study.

Noncatastrophic Impacts. Although on a different scale than catastrophic risks, controversies abound in the valuation of noncatastrophic impacts from future climate change. These include damages to world agriculture, costs of increased storm intensity and protecting against rising sea levels, health impacts from heat waves and the possible spread of vector-borne disease, loss of ecosystems, and so on. Box 1 provides a very brief summary of attempts to value these damage categories (see Eber and Krupnick 2009 for a more detailed discussion). However, due to the rapid outdating of prior research, daunting methodological challenges, and the small number of economists working on Pigouvian tax assessment, the valuation literature on aggregate, noncatastrophic damages remains highly inconsistent and poorly developed, as a few examples illustrate (see also Hanemann 2008).

Damage assessments find worldwide agricultural impacts are anything from a net gain of about 0.1 percent to a net loss of 0.2 percent of GDP for warming of about $2.5^{\circ} \mathrm{C}$ occurring in 
2100 , but these figures are at odds with more recent evidence suggesting larger net losses. ${ }^{14}$ Similarly, the most recent evidence on ice melting suggests that sea level rises over the next century may be more extreme than the $25-60 \mathrm{~cm}$ projected by IPCC (2007) and assumed in most previous damage assessment work (Box 1). And estimates that damages to ecosystems amount to about $0.1-0.2$ percent of world GDP seem inconsistent with the projection by Fischlin et al. (2007) that 20-30 percent of the world's species (an enormous amount of natural capital) faces some (though possibly slight) extinction risk.

More generally, scientific models cannot reliably predict local changes in average temperature, temperature variability, and precipitation, all of which are critical to crop yields. The baseline for impact assessment decades from now is highly sensitive to assumptions about regional development (including the ability to adapt to climate change), future technological change (e.g., the development of climate- and flood-resistant crops), and other policies (e.g., attempts to eradicate malaria or integrate global food markets). Controversies surround the valuing of nonmarket effects (e.g., the value of mortality in poor countries, or how much people in wealthy countries value ecosystem preservation in poor countries). At best there is little evidence on additional risks, such as extreme local climate change (e.g., from shifting monsoons and deserts), large sea level rises that could occur if the West Antarctic ice sheets melt, and broader health effects (e.g., malnutrition from food shortages, the net effects of milder winters and hotter summers, and diarrhea if droughts reduce safe drinking water supplies). Most of the impact assessment literature is based on extrapolations from U.S. studies - country-specific studies that account for local factors (e.g., the ability to adapt farm practices to changing climate) have only recently begun to emerge. Finally, worldwide results mask huge disparities in regional burdens, and there is disagreement on how to aggregate impacts across regions with very different per capita income. ${ }^{15}$

\footnotetext{
${ }^{14}$ For example, Schlenker et al. (2005) suggest that the output of some crops in the United States could fall by as much as 70 percent by 2100 , under warming in the absence of mitigation policy. Cline (2007) suggests BAU losses of agricultural output in developing countries in the order of 30 percent, while Guiteras (2008) estimates agricultural losses of 30-40 percent for India.

${ }^{15}$ Most studies aggregate regional impacts by using weights equal to the region's share in world GDP or world population. More generally, use of distributional weights can increase total damage estimates up to about 300 percent (e.g., Pearce 2005).
} 


\subsubsection{Further Issues Posed by Uncertainty}

Finally, we touch on some additional complications for emissions pricing posed by stochastic discount rates, risk aversion, and irreversibility.

In estimating the discounted value of future damages from additional emissions, the standard approach is to treat the future time path of discount rates, and hence discount factors applied to future damages, as nonstochastic. However, the discount factor is a convex function of the future discount rate, so allowing for uncertainty about a given expected value for the discount rate increases the discount factor (especially for more distant future periods), and hence the present discounted value of future damages (Weitzman 1998). This issue turns out to be empirically important. In particular, Newell and Pizer (2003) estimated that uncertainty over future discount rates (inferred from historical evidence for the United States) almost doubles estimates of Pigouvian emissions taxes for a given (mean) discount rate.

Leaving aside extreme risks, should Pigouvian tax estimates include a premium reflecting risk aversion to uncertainty over future global warming damages (i.e., concavity in the utility function)? A risk premium would be appropriate if the marginal utility of consumption, net of climate damages, were larger in high-damage cases, in which case a mean-preserving increase in the spread of possible damage outcomes increases expected disutility. However, if gross consumption is greater in high-damage scenarios (e.g., because rapid technological advance leads to both high consumption and high emissions rates), then the marginal utility of consumption net of damages is lower, and possibly even lower than marginal utility in lowdamage states. Simulations by Nordhaus (2008, ch. 7) suggest this might in fact be the case, implying the risk premium is actually negative, though empirically small.

Finally, we return to the issue of irreversibility and future learning, in particular whether there is an option value (which should be reflected in the current emissions price) gained from delaying atmospheric GHG accumulations until more is known about how much damage they will cause. Option values arise if delaying additions to the atmospheric GHG concentration increases the potential welfare gains in the future from responding to new information on the seriousness of global warming. If damages are linear in atmospheric GHG concentrations, which may be a reasonable approximation in the absence of threshold effects, changes in the inherited concentration level do not affect the marginal damage schedule from additional, future accumulations. In this case, the welfare effects of policy interventions at different time periods are decoupled (at least from the damage side), and there is no option value. Moreover, to the extent that current abatement involves (nonrecoverable) sunk investments in emissions-saving 
technologies, there is an option value from delaying long-lived emissions-saving investments until more is known about the benefits of emissions reductions (Kolstad 1996a). For these reasons, theoretical analyses suggest that the prospect of future learning justifies less near-term abatement (Kolstad 1996b; Fisher and Narain 2003). However, as already noted, the critical exception to this is when there is a possibility of crossing a catastrophic threshold in atmospheric concentrations prior to future learning, which is essentially nonreversible given the nonnegativity constraint on future emissions (Pindyck 2007).

\subsubsection{Summary}

Most estimates of near-term Pigouvian taxes (or marginal damages) are in the order of about \$5-25 per ton of $\mathrm{CO}_{2}$. This range is in the same ballpark as near-term emissions prices consistent with least-cost stabilization of atmospheric $\mathrm{CO}_{2}$ concentrations at $550 \mathrm{ppm}$. These prices represent a lower bound on appropriate policy stringency. Much higher Pigouvian tax estimates (that are consistent with $450 \mathrm{ppm}$, or even more stringent, $\mathrm{CO}_{2}$ stabilization targets) are implied with a zero rate of pure time preference, though analysts are strongly divided on this issue. Much higher prices may also be warranted on the grounds of extreme catastrophic risks, depending on the shape of the climate sensitivity distribution, which is uncertain. Even the reliability of noncatastrophic damages risks is an open question. But the bottom line is that, whether moderate or aggressive emissions pricing would be efficient at present largely hinges on one's view of discounting, whether radical midcourse corrections in response to learning about catastrophic risks are feasible, and the prospects for development of last-resort technologies.

\section{Policy Design}

\subsection{Choice and Design of Domestic Emissions Control Instruments}

Debate over the choice of domestic emissions control instruments is no longer primarily about the superiority of market-based approaches over traditional forms of regulation (like technology mandates), but rather between the two market-based alternatives, emissions taxes and 
cap-and-trade systems. ${ }^{16}$ In a world where the emissions externality is the only market distortion and there is no uncertainty, either instrument could achieve the first-best outcome if the emissions cap at each date equals the emissions that would result under the Pigouvian tax. Whether allowances are auctioned or given away for free has distributional consequences but does not affect efficiency in this setting, so long as firm behavior does not influence their future allowance allocations. If firms were free to bank and borrow emissions allowances, the policies would still be equivalent, if the permit trading ratios across different time periods were equivalent to the ratio of Pigouvian emissions taxes at those dates (Kling and Rubin 1997).

The equivalence between the two instruments potentially breaks down in the presence of preexisting tax distortions, when distributional impacts are a concern, and when there is uncertainty. Despite these complications, to a large extent permit systems can be designed to mimic the effect of a tax, and vice versa, and therefore the choice of instrument per se is less important than whether the chosen instrument is well designed (Goulder 2009). Aside from policy stringency, key design features relate to the point and scope of regulation, the allocation of policy rents, and possible provisions to limit price volatility.

\subsubsection{Point and Scope of Regulation}

Either a $\mathrm{CO}_{2}$ tax or cap-and-trade system can be imposed upstream where fuels enter the economy according to a fuel's carbon content or, as in the European trading program, to downstream emitters at the point where fuels are combusted. ${ }^{17}$ For a given total emissions reduction, the estimated costs of downstream programs out to 2030 are not dramatically larger

\footnotetext{
${ }^{16}$ Market-based instruments equalize marginal abatement costs across all abatement opportunities within the firm, across heterogeneous firms, across production sectors, and across households and firms by establishing a uniform, nationwide emissions price (Dales 1968; Kneese and Bower 1968; Baumol and Oates 1971; Montgomery 1972). In contrast, for example, a requirement that all electric utilities generate a fraction of their power from renewables will not achieve any of these efficiency conditions. Some opportunities at the firm level (e.g., substituting natural gas and nuclear power for coal) are not exploited; marginal costs will differ across heterogeneous power companies; household electricity prices will not reflect the cost of the remaining (unpriced) emissions; and abatement opportunities outside of the power sector are unexploited.

${ }_{17}$ Regulating $\mathrm{CO}_{2}$ emissions at upstream facilities would likely involve fewer than 3,000 entities in the United States (coal mines or large burning coal facilities, oil refineries, and natural gas processors) while a purely downstream approach that regulates only large stationary emitters (primarily electricity generators and industrial sources) would likely involve about 10,000 entities (Hall 2007).
}

If introduced at the same points in the economy, $\mathrm{CO}_{2}$ taxes and cap-and-trade systems are likely to have very similar administrative costs. Under cap-and-trade, costs also include those from administering trading markets as well as the transactions costs of the trades themselves, though these are relatively small (Stavins 1995). 
than those for comprehensive upstream systems - about 20 percent larger according to Goulder (2009) — even though downstream programs cover only about half of total U.S. and E.U. CO 2 emissions. This is because the huge bulk of low-cost abatement opportunities are (at least initially) in the power sector. Moreover, the infeasibility of monitoring emissions from vehicles, home heating fuels, and small-scale industrial boilers in a downstream system can be largely addressed through midstream measures targeted at refined transportation and heating fuels, which further narrows the cost discrepancy between upstream and downstream systems.

There are two further differences between upstream and downstream programs. One is that upstream systems must be combined with a crediting system to encourage development and downstream adoption of carbon capture and storage technologies at coal plants and industrial sources. The tax credit should equal the amount of carbon sequestered (measured by continuous emissions monitoring systems) times the emissions price. The other is that, at least for the United States where many states retain cost-of-service regulation in the power sector, the opportunity cost of freely allocated emissions allowances to electric utilities in a downstream system may not be passed forward into higher generation prices. As a result, incentives for electricity conservation could be a lot weaker than in comparable upstream programs (where higher fuel prices can be passed forward), or in downstream programs with full allowance auctioning, resulting in a significant loss in cost-effectiveness (Burtraw et al. 2001).

Should regulations cover the embodied carbon content in products imported from countries with no emissions controls? If embodied carbon is not covered, there is a risk of international emissions leakage. Although very difficult to predict, some estimates suggest that as much as 15-25 percent of U.S. $\mathrm{CO}_{2}$ reductions could be offset by higher emissions in other countries if they do not have comparable emission policies (Gupta et al. 2007; Ho et al. 2008). The problem is most significant for downstream, energy-intensive firms competing in global markets (e.g., chemicals and plastics, primary metals, petroleum refining), where reduced production at home may be largely offset by increased production in other countries with higher emissions intensity than in the United States (Fischer and Fox 2007, 2009). One possible response is to impose taxes, or permit requirements, according to the embodied carbon of imported products (and symmetrical rebates for exporters). Another would be to subsidize the output of leakage-prone industries (according to Fischer and Fox [2009] the financial cost of offsetting the cost of direct emissions liabilities would be about 6 percent of emissions tax revenues), or equivalently, grant them output-based allocations of free emissions allowances. But either approach may run afoul of free trade obligations, and neither addresses leakage due to 
reductions in global fuel prices, which is responsible for the majority of the overall leakage rate in some models (Babiker and Rutherford 2005; Ho et al. 2008; Fischer and Fox 2009).

Certain non- $\mathrm{CO}_{2} \mathrm{GHG}$ are easily monitored (e.g., vented methane from underground coal mines, fluorinated gases used in refrigerants and air conditioners) and could be directly integrated into a $\mathrm{CO}_{2}$ mitigation program through taxes, or permit trading ratios, reflecting their relative lifetime warming potential. Other gases are far more difficult to monitor and are probably better incorporated, insofar as possible, through offset provisions, where the onus falls on the individual entity to demonstrate valid reductions relative to a credible baseline. For example, methane from landfills and livestock waste might be collected by using an impermeable cover, and flared or used in onsite power generation, while nitrous oxide might be reduced through changes in tilling and fertilizer use (e.g., Shih et al. 2006; Hall 2007).

Finally, $\mathrm{CO}_{2}$ abatement through forest carbon sequestration (e.g., from reducing deforestation, reforesting abandoned cropland and harvested timberland, modifying harvest practices to reduce soil disturbance) appears to be relatively cost-effective. According to Stavins and Richards (2005), in the United States as much as 1.8 billion tons of $\mathrm{CO}_{2}$ a year (almost 30 percent of U.S. fossil fuel $\mathrm{CO}_{2}$ emissions) might be sequestered at a cost of up to about $\$ 20$ per ton of $\mathrm{CO}_{2}$. Coupling a domestic mitigation program with offset provisions for forest carbon sequestration will require measuring regional forest inventories to establish baselines, monitoring changes in forest use (through remote sensing and ground-level sampling) relative to the baseline, and inferring the emissions implications of these changes based on sampling of local tree species and age. However, even if these monitoring challenges can be overcome, further problems remain. One is that, without an international program covering major forested countries, domestic reductions can be offset through emissions leakage as reduced domestic timber production increases world timber prices. ${ }^{18}$ Another is that sequestered carbon in trees is not necessarily permanent if trees are later cut down, decay, or burn, requiring assignment of liability to either the offset buyer or seller for the lost carbon.

\subsubsection{Allocation of Policy Rents}

In their traditional form, emissions taxes raise revenues for the government, while capand-trade systems create rents for firms receiving allowance allocations for free. However,

\footnotetext{
18 Even within a country, studies suggest leakages rates could be quite high unless the entire forest sector is included in the program (e.g., Murray et al. 2004, Sohngen and Brown 2004).
} 
through allowance auctions, cap-and-trade systems can generate comparable revenues to a tax, while rents can be provided under a tax through inframarginal exemptions for emissions or carbon content. Under either instrument, the fraction of policy rents accruing to the government rather than private firms, and whether revenues are used for cutting distortionary taxes or other purposes, can be of considerable importance, for both efficiency and distributional reasons.

Preexisting Tax Distortions and Fiscal Considerations. The implications for emissions control policies of preexisting tax distortions in factor markets have received considerable attention in the broader environmental economics literature (e.g., Bovenberg and Goulder 2002), though these distortions are typically not integrated into energy-climate models. This raises two issues: to what extent is there a cost savings from policies that raise revenues and use them to offset distortionary taxes like income and payroll taxes, and to what extent might there be a bias in estimates of climate policy costs from models that ignore prior tax distortions?

The efficiency gain from recycling revenues in other tax reductions (relative to returning them lump sum or leaving policy rents in the private sector) is simply the amount of revenue raised times the marginal excess burden of taxation (i.e., the efficiency loss from an increase in that tax per extra dollar of revenue raised). Although there is uncertainty over behavioral responses in factor markets, a typical assumption is that the marginal excess burden of income taxes is around $\$ 0.25$ for the United States, or perhaps as high as $\$ 0.40$ if distortions in the pattern of spending created by tax preferences (e.g., for employer medical insurance or homeownership) are taken into account (e.g., Parry and Bento 2000). For modest carbon policies, the efficiency gain from revenue recycling can be large relative to the direct efficiency cost of the policy, or Harberger triangle under the marginal abatement cost schedule. For example, if a $\$ 20$ tax on U.S. $\mathrm{CO}_{2}$ emissions (currently about 6 billion tons) reduces annual emissions by 10 percent, the Harberger triangle is $\$ 6$ billion, while the revenue-recycling benefit is around $\$ 30$ 40 billion per year.

However, this does not necessarily mean that revenue-neutral $\mathrm{CO}_{2}$ taxes, or auctioned allowance systems, produce a "double dividend" by reducing the costs of the broader tax system in addition to slowing climate change. There is a counteracting, "tax-interaction" effect (e.g., Goulder 1995). Specifically, the (policy-induced) increase in energy prices drives up the general price level, which reduces real factor returns, and thereby (slightly) reduces factor supply and efficiency. Most analytical and numerical analyses find that the tax-interaction effect exceeds the revenue-recycling effect, implying no double dividend, and that abatement costs are actually higher due to the presence of preexisting tax distortions. A rough rule of thumb from these models is that the costs of revenue-neutral emissions taxes are about 15 percent greater than the 
direct cost due to interactions with prior tax distortions, implying the optimal tax is 15 percent lower than the Pigouvian tax (e.g., Bovenberg and Goulder 2002). ${ }^{19}$ However, the cost increase is far more substantial for policies that do not exploit the revenue-recycling effect (i.e., cap-andtrade with free allowance allocation or $\mathrm{CO}_{2}$ taxes with revenues not used to increase economic efficiency). According to cost mark-up formulas derived in Goulder et al. (1999), the increase exceeds 100 percent when the emissions reduction is below 30 percent. $^{20}$

More generally, there are many ways that carbon policy revenues might be used, such as funding technology programs, climate adaptation projects, deficit reduction, energy efficiency programs, rebates to electricity consumers, and any number of complex adjustments to the tax system, though the efficiency implications of these recycling options have received little attention in the literature. Although in recent years there has been a dramatic shift away from free to largely auctioned permit systems in actual and proposed carbon policies, in some cases it is unclear how the revenues will be spent. ${ }^{21}$ Therefore, unless legislation accompanying carbon policies specifies offsetting reductions in other distortionary taxes, whether and to what extent this shift implies a large reduction in the costs of carbon policies is unclear.

Distributional Considerations. The distributional impacts of emissions control policies are potentially important for both equity and political feasibility.

\footnotetext{
19 Other CGE models representing a broader range of taxes, tariffs, and terms of trade effects find that a carbon policy with revenue recycling can have negligible or even positive effects on domestic welfare (e.g., Fischer and Fox 2007). Given these multiple pre-existing distortions, then, grandfathering can be even more costly.

20 There are some caveats here. One is that the proportionate increase in abatement costs may be much smaller in other countries if tax wedges in factor markets are smaller than those in the United States, or if labor markets are dominated by institutional wage setting (e.g., Bosello et al. 2001). Another caveat is that the tax-interaction effect is weaker if, due to regulated pricing and/or differences in baseload and peak generation technologies, emissions prices are not fully passed forward into higher electricity prices for households (Bento and Jacobsen 2007; Parry 2005). Finally, the revenue-recycling effect can dominate the tax-interaction effect when income tax preferences distort the pattern of spending (in addition to factor markets) and when a disproportionately large share of revenues are used to cut taxes on capital, as opposed to labor; see Parry and Bento (2000) and Bovenberg and Goulder (1997), respectively.

${ }^{21}$ For example, in the first two phases of the E.U.'s $\mathrm{CO}_{2}$ trading program (2005-2007 and 2008-2012), over 95 percent of the allowances were given away free to existing emissions sources. However, partly in response to the large windfall profits estimated to have been earned by power companies, the plan is to transition to full allowance auctions by 2020, with the decision on how to use revenues largely left to the member states (Sijm et al. 2006; CEC 2008). In the Regional Greenhouse Gas Initiative in the United States, covering power sector $\mathrm{CO}_{2}$ emissions from ten northeastern and midatlantic states, allowances are auctioned with revenues earmarked for energy efficiency and other clean technology programs.
} 
On equity grounds, the difference between (revenue-neutral) $\mathrm{CO}_{2}$ taxes/auctioned allowances and freely allocated allowance systems can also be quite striking. Under the latter policy, permit rents are reflected in higher firm equity values, and therefore (through dividend and capital gains income) ultimately accrue to shareholders, who are concentrated in upper income groups. In fact, Dinan and Rogers (2002) estimated that, for a 15 percent reduction in $\mathrm{CO}_{2}$ emissions, U.S. households in the lowest-income quintile would be worse off on average by around $\$ 500$ per year, while households in the top-income quintile reap a net gain of around $\$ 1,000$ (i.e., increased stockholder wealth overcompensates this group for higher energy prices). This inequitable outcome could be avoided under emissions taxes and auctioned allowance systems if revenues were recycled in income tax reductions, somewhat tilted toward lowerincome groups, to offset the effect of their disproportionately higher budget shares for energy goods (e.g., Metcalf 2009).

As regards political feasibility, compensation for adversely affected industries may also be part of the political deal-making needed to first initiate, and then progressively tighten, emissions controls (e.g., Ellerman 2005). Compensation through free allowance allocation or tax relief may be required for both formally regulated sectors and other sectors vulnerable to higher energy prices (e.g., firms competing in global markets with limited ability to absorb higher energy costs caused by upstream regulation). However, given the tension between providing industry compensation and the fiscal and (household) equity reasons for raising revenue, it is important to understand how much compensation would be needed to keep firms whole. At least for a moderately scaled $\mathrm{CO}_{2}$ permit system, only about 15-20 percent of allowances are needed to compensate energy-intensive industries, on the whole, for their loss of producer surplus, so the huge bulk of the allowances could still be auctioned (Bovenberg and Goulder 2001; Smith et al. 2002). ${ }^{22}$ Although there are reasons for phasing out compensation over time, firms may still be

\footnotetext{
${ }^{22}$ However, Burtraw and Palmer (2008) find that due to heterogeneity in net compliance costs across firms, a much larger fraction of allowance value would be necessary to fully compensate all individual firms, due to overcompensation for other firms.
} 
amenable to this if they receive excess compensation in the early years of the program (e.g., Stavins 2007). ${ }^{23}$

On the other hand, political feasibility may be influenced as much by desires to maintain levels of economic activity and employment than just profits. Free allocations to preserve shareholder value do little to preserve competitiveness and deter leakage, since marginal cost pressures are unaffected. Updated, output-based allocations lower variable costs, as opposed to fixed costs, and thereby mitigate competitiveness effects, with benefits passed on to consumers, rather than just producers (Fischer and Fox 2009). However, such instruments can be counterproductive if applied beyond trade-sensitive energy intensive manufacturing to sectors in which higher prices are an effective means for signaling conservation (as in electricity or refined petroleum products). Furthermore, it must be emphasized that the benefits of revenue recycling, increasing the real wage and lowering the costs of capital, accrue to all sectors in the economy and improve domestic competitiveness across the board.

\subsubsection{Price Volatility}

One reason $\mathrm{CO}_{2}$ taxes and cap-and-trade systems may produce different outcomes, even when comparably designed, stems from uncertainty over future abatement costs reflecting, for example, uncertainty over baseline emissions in the absence of policy, energy prices, technological advances, and substitutes for fossil fuels.

Price versus Quantity Instruments in Their Pure Form. If the goal is welfare maximization, abatement cost uncertainty strongly favors emissions taxes over cap-and-trade systems in their pure form. This is most easily seen in a static setting where the marginal benefits from emissions abatement are assumed constant and known. In this case, a Pigouvian emissions tax automatically equates marginal benefits to marginal abatement costs, regardless of the position of the marginal abatement cost schedule. In contrast, with emissions capped to equate marginal benefits with ex ante expected marginal abatement costs, ex post abatement will either

\footnotetext{
${ }^{23}$ One reason for phasing out allowance allocations is that they must initially be based on a firm's historical emissions rates (prior to program implementation), which may be viewed as increasingly unfair as firms grow or contract at different rates, or change their fuel mix, over time. However, any updating of baselines based on firm performance will likely introduce distortions in firm behavior (Rosendahl 2008). Free allowance allocation may also retard the exit of inefficient firms from an industry if firms lose their rights to future allocations if they go out of business.
} 
be too high or too low depending on whether the marginal abatement cost schedule is higher or lower than expected (Weitzman 1974; Roberts and Spence 1976; Yohe 1978).

This basic result carries over to a dynamic context with a sequence of annual (Pigouvian) taxes or emissions caps, and where environmental damages depend on the accumulated atmospheric stock of emissions. Here, we have strong reasons to believe that the marginal benefits from global emissions reductions are essentially constant over a significant range, as abatement in any one year has minimal impact on the atmospheric stock. In fact, with abatement cost uncertainty, simulation analyses suggest that discounted welfare gains under (globally imposed) $\mathrm{CO}_{2}$ taxes might be several times those under (equivalently scaled) permits (e.g., Pizer 2003; Hoel and Karp 2002). A qualification to this is that the welfare advantage of taxes is less pronounced if abatement cost shocks persist over time (Newell and Pizer 2003) and the emissions cap can be adjusted in response to those shocks (e.g., Karp and Zhang 2005). While not explicitly quantified in the literature, we would expect a global emissions tax, growing at approximately the interest rate, to have a substantial cost advantage over an equivalently scaled set of annual emissions caps, when the policy objective is least-cost stabilization of global climate rather than welfare maximization. Unlike the situation under the tax, discounted marginal abatement costs at different dates diverge under fixed emissions caps and cost uncertainty.

Stabilizing Allowance Prices. Emissions price volatility under cap-and-trade systems can be contained by allowing firms to bank permits when permit prices (and marginal abatement costs) are low and borrow permits from future periods when prevailing prices are high. In fact, if 1-for-1 banking and borrowing were completely unlimited and costless, expected allowance prices would rise at the interest rate, and the system would be largely equivalent to that of an emissions tax growing at the interest rate (Newell et al. 2005). Alternatively, through establishing appropriate ratios for trading permits across time, the allowance price trajectory could mimic the growth in marginal emissions damages, or the Pigouvian tax, over time (e.g., Kling and Rubin 1997).

In fact, most existing cap-and-trade systems (e.g., the federal $\mathrm{SO}_{2}$ and $\mathrm{NO}_{x}$ programs and regional $\mathrm{CO}_{2}$ programs in the United States and the E.U.'s $\mathrm{CO}_{2}$ program) now incorporate banking provisions, though in response to concerns about default risk, borrowing is typically not permitted or is subject to an interest penalty and/or quantitative limits. Fell et al. (2008) estimate that banking and borrowing provisions contained in leading U.S. climate proposals obtain about one-quarter to one-half of the cost savings from emissions taxes over equivalent cap-and-trade systems without these provisions. 
An alternative approach is to limit price volatility through a "safety valve," where the government sells additional permits at a fixed price to prevent allowance prices from rising above a ceiling price (e.g., Jacoby and Ellerman 2004). Expected welfare under this policy is maximized by essentially designing it to mimic a Pigouvian tax - that is, by setting the safety valve price equal to marginal emissions damages and the emissions cap tight enough so the safety valve binds nearly all the time (Pizer 2003). Intermediate cases (with higher safety valve prices and/or less stringent caps) generate intermediate welfare gains between those of the pure tax and emissions quota. A further alternative is a symmetric safety valve (or price collar), which combines a price ceiling with a price floor (Burtraw et al. 2009). This approach encourages additional abatement when allowance prices are low (to offset reduced abatement when allowance prices are high) and offsets the potentially harmful impacts of the price ceiling on incentives to invest in emissions-saving technologies.

According to Fell et al. (2008), on an annualized basis the cost savings to the United States between emissions taxes and fixed emissions quotas is about $\$ 4$ billion for an emissions price of around $\$ 20$ per ton of $\mathrm{CO}_{2}$ (with intermediate cases like safety valves, symmetric safety valves, and banking and borrowing provisions yielding intermediate cost savings).

One final twist in the comparison of alternative instruments is that the price flexibility afforded by a cap-and-trade system with (unhindered) allowance borrowing and banking could actually be advantageous from a social welfare perspective, when there is learning about future damages, and emissions taxes (or safety valves) are only adjusted at discrete intervals (Murray et al. 2009). ${ }^{24}$ Under the former policy, new information about damages will be immediately reflected in the time path of current and expected future allowance prices, as speculators anticipate an adjustment of future emissions targets in response to that information. In contrast, it may take some time before emissions taxes, or price floors and ceilings accompanying cap-andtrade programs, can be adjusted to reflect this new information, leaving emissions prices suboptimal during the period of policy stickiness.

\footnotetext{
${ }^{24}$ Uncertainty over the marginal benefit schedule, in the absence of learning, would not affect the choice between emissions taxes and cap-and-trade because, on average, cumulated emissions reductions, and hence expected environmental benefits, are the same under both instruments (e.g., Stavins 1996). This assumes marginal benefits and costs are uncorrelated, which is plausible, for the most part, as uncertainty over the former is largely driven by scientific factors while uncertainty over the latter largely reflects economic factors. The main caveat to this, already discussed, is the is the possibility that the marginal utility of consumption may vary across different damage states.
} 


\subsection{Promoting Technology Development and Diffusion}

Several studies have demonstrated the central role that the availability and cost of advanced energy technologies play in determining the future costs of GHG emissions targets (e.g., Clarke et al. 2006; Edmonds et al. 2000; Gillingham et al. 2008). For example, Clarke et al. (2006) found that accelerated technology development can reduce discounted global abatement costs by 50 percent or more. Establishing a price on $\mathrm{CO}_{2}$ emissions is the single most important policy for encouraging the innovation and adoption of emissions-saving technologies. However, additional measures to promote applied $\mathrm{R} \& \mathrm{D}$, more basic research, and technology deployment may be justified to the extent they address market failures at different stages of the innovation process. $^{25}$

\subsubsection{R\&D Policy}

One market failure stems from the inability of private sector inventors or innovators to fully appropriate spillover benefits to other firms that might copy a new technology, imitate around the technology if it is under patent, or otherwise use knowledge about the technology to advance their own research programs (Jaffe et al. 2003; Popp et al. 2009). Numerous empirical studies suggest that technology spillovers cause the (marginal) social return to (commercial) $\mathrm{R} \& \mathrm{D}$ to be several times the (marginal) private return. ${ }^{26}$

The appropriability problem implies that R\&D incentives will be suboptimal, even under Pigouvian emissions pricing. One response would simply be to set emissions prices at a level higher than warranted by the climate externality. However, this would generate efficiency losses from excessive short-term abatement and would not differentiate incentives across technologies that might face very different market impediments. In fact, no single instrument-either emissions pricing or R\&D incentives - can effectively correct both the emissions externality and

\footnotetext{
${ }^{25}$ Fischer (2008) discusses how the extent to which public support for R\&D depends on the extent to which the emissions externality is priced.

${ }^{26}$ For example, see Griliches (1992), Mansfield (1985), and Jones and Williams (1998). Although there is a possibility of excessive competition for a given amount of innovation rent, analogous to the excessive competition for open-access resources, this problem is generally thought to be dominated by the imperfect appropriability effect (Griliches 1992). In fact, the problem of suboptimal innovation incentives may be especially severe for GHG-saving technologies compared with commercial technologies. For example, skepticism over long-term commitments to emissions pricing, and the desirability of retaining policy discretion to respond to future scientific knowledge, undermine the durable and substantial incentives needed for encouraging GHG-saving technology investments with high up-front costs. Nonetheless, over a long horizon, the potential global efficiency gains from correcting the R\&D market failure appear to be smaller than those from correcting the $\mathrm{CO}_{2}$ emissions externality (Parry et al. 2003).
} 
the knowledge appropriability problem: using one instrument alone may involve considerably higher costs than employing two complementary instruments (Fischer and Newell 2008; Goulder and Schneider 1999). ${ }^{27}$

Unfortunately, available literature provides limited guidance on the design of complementary R\&D instruments. It is not clear which instrument among, for instance, research subsidies, strengthened patent rules, or technology prizes, is most efficient, as this depends on the magnitude of technology spillovers, the scope for monopoly pricing under patents, and asymmetric information between governments and firms about the expected benefits and costs of research (e.g., Wright 1983). And just how much or how fast we should be pushing applied R\&D is also unclear, given uncertainty about the likelihood that research will lead to viable technologies and the potential for short-term crowding out of other socially valuable research elsewhere in the economy (e.g., Nordhaus 2002; Goulder and Schneider 1999).

\subsubsection{Basic Research}

Appropriability problems are most severe for more basic research, which is largely conducted by universities, other nonprofits, and federal labs, mostly through central government funding. While it is not practical to assess the efficient allocation of funding across individual programs, Newell $(2008,32)$ suggests that a doubling of U.S. federal climate mitigation research spending (currently about $\$ 4$ billion a year) is consistent with plausible assumptions about the rate of return on such spending. To avoid crowding out, this could be phased in with a progressive expansion of the supply of engineering and science college graduates.

\subsubsection{Deployment Policy}

In principle there are several possibilities for market failures at the technology deployment stage. For example, through learning-by-doing, early adopters of a new technology (e.g., a cellulosic ethanol plant) may lower production costs for later adopters (e.g., van Bentham et al. 2008). But since the potential for these spillovers may vary greatly depending on industry structure, the maturity of the technology, and so forth, any case for early adoption subsidies

\footnotetext{
27 Studies that compare R\&D incentives under alternative emissions control policies (e.g., Milliman and Prince 1989; Jung et al. 1996; Fischer et al. 2003) find relatively little difference between (equivalently scaled) emissions taxes and permit systems, so long as the potential for technological innovation is modest during the period for which instruments are fixed. However, these studies are deterministic; the impact of emissions price volatility under capand-trade systems on reducing R\&D incentives has received little empirical attention.
} 
needs to be considered on a case-by-case basis. Another possibility is consumer undervaluation of energy efficiency, which is a key rationale for regulations governing auto fuel economy and household appliances. However, the consumer valuation hypothesis (in effect, that consumers excessively discount energy savings from more efficient technologies) has now been debated, inconclusively, for three decades (e.g., Gillingham et al. 2009). Other market imperfections might include asymmetric information between project developers and lenders, network effects in large integrated systems, and incomplete insurance markets for liability associated with specific technologies.

However, due to a lack of solid empirical evidence, little can be said with confidence about the magnitude of these market failure possibilities and thus the degree to which they warrant additional policy interventions. This is an important area for future study, given the significant degree of current policy interest in energy policy (e.g., subsidies and mandates for renewable electricity and transport fuels, automobile fuel economy, and energy-efficient lighting and equipment).

\subsection{International Policy Design}

Proposed architectures for international emissions control regimes can be loosely classified into those based on (1) bottom-up approaches that progressively integrate regional initiatives versus top-down, globally negotiated approaches, and (2) cap-and-trade systems versus systems of emissions taxes (e.g., Aldy and Stavins 2007). There is disagreement over which type of architecture is most desirable and most likely to emerge in practice. In the bottomup approach, norms for participation might evolve from small groups of countries launching regional programs that progressively expand and integrate, or by explicit linking of domestic cap-and-trade programs (e.g., Carraro 2007; Jaffe and Stavins 2008; Victor 2007). Alternatively, countries might regularly pledge emissions reductions with periodic reviews by a formal institution (e.g., Schelling 2007; Pizer 2007). Here we focus on top-down approaches, given that advocates of rapid climate stabilization tend to favor internationally binding commitments.

The most daunting challenge is designing an architecture that encourages participation among the world's largest GHG emitters - the Kyoto framework failed to do this as non-Annex 1 countries, including China, Brazil, South Africa, Mexico, and Indonesia, had no emissions 
control obligations, while the United States withdrew from the agreement. ${ }^{28}$ Broad participation is needed - at least over the longer term and possibly also the near term under a stringent climate stabilization target (see above) - to promote the cost-effectiveness of any international agreement and limit concerns about international competitiveness and emissions leakage. Participation of developing countries through the Clean Development Mechanism (CDM), as at present, does not reduce global emissions - it only lowers the cost to developed countries of meeting their emissions goals by allowing firms to purchase (lower-cost) emissions reductions in developing countries on a project-by-project basis. Moreover, there is considerable concern that some CDM credits may not represent truly additional reductions, due to the difficulty of establishing a baseline against which reductions can be measured, in which case the CDM serves to increase global emissions (e.g., Keeler and Thompson 2008; Rosendahl and Strand 2008).

To be successful, each country must perceive an emissions control agreement as equitable in terms of sharing the burden of global mitigation costs. Usually this means that industrial countries bear a disproportionately greater cost burden due to their higher per capita income and greater contribution to historical GHG accumulations. ${ }^{29}$ In contrast, as noted above, under a globally cost-effective pricing agreement with no side payments, developed countries may bear two-thirds or more of gross discounted global abatement costs over the next century. Negotiations are further hampered, under a Kyoto type of framework, by the need to agree on emissions quotas for every participating country, and to periodically renegotiate these quotas, which can be contentious if economies expand at different rates during interim periods.

Frankel (2009) offers a global cap-and-trade proposal that addresses equity through imposing no cost burden on developing countries in the early years, and subsequently a cost burden comparable to those previously borne by others at a similar stage of economic development. Global cost-effectiveness is preserved, and emissions leakage avoided, by establishing a harmonized emissions price by immediately incorporating all countries into the global trading system, with low-income countries initially allocated emissions caps equal to their

\footnotetext{
${ }^{28}$ China's $\mathrm{CO}_{2}$ emissions now exceed those for the United States, while India's exceed those of Japan (EIA 2008b, Table A10). In fact, 50 non-Annex 1 countries now have per capita income greater than that of the poorest Annex 1 countries.

${ }^{29}$ There is some dispute over historical responsibilities, however. Although industrial countries are responsible for about 80 percent of historical fossil fuel emissions, when releases from land-use changes are taken into account Mueller et al. (2007) suggest that poor countries are responsible for 45 percent of the increase in atmospheric $\mathrm{CO}_{2}$ accumulations.
} 
projected emissions. Effectively, the pattern of stringent and lax quota allocations among developed and developing countries creates a system of side payments from developed countries (who are net permit buyers) which overcompensates developing countries (who are net permit sellers) for the costs of their (inframarginal) emissions reductions. Furthermore, negotiations are greatly simplified by the establishment of simple formulas that automatically start reducing developing country quotas once their per capita income, or per capita emissions, cross certain thresholds.

A globally harmonized $\mathrm{CO}_{2}$ tax can be designed to essentially replicate this cap-and-trade system, so there appears to be little reason, in this regard, for preferring one instrument over the other. Instead of agreeing on a global emissions cap, and how it adjusts over time, countries would need to agree on a harmonized tax rate, and how this rate is increased over time. And instead of negotiating over rules relating quota allocations to the evolution of per capita income (or emissions) over time, countries would need to agree on rules for explicit side payments related to a country's per capita income (or emissions).

However, under either the cap-and-trade or tax-based approach, there is an obvious tension between compensating developing nations and policy stringency. For example, Jacoby et al. (2008) estimate that under a global policy that stabilizes $\mathrm{CO}_{2}$ concentrations at (approximately) $450 \mathrm{ppm}$, compensation for developing countries would entail (explicit or implicit) side payments by the United States of at least \$200 billion in 2020 under different burden sharing arrangements (or ten times current U.S. development assistance). This appears to call into question the credibility of such compensation schemes. Even with less than full compensation, the international transfers are of unprecedented scale. In this regard, granting these countries initial quota allocations equal to their BAU emissions is unnecessarily high to entice participation, as it provides roughly twice the compensation needed to cover abatement costs (in the absence of other distortions, excess compensation is the value of the allowances sold to other countries less the integral under the marginal abatement cost curve).

As regards verification of policies, one potential problem with an emissions tax is that countries may undermine its effect through changes in other energy taxes. In principle, countries might be pressured to adjust their emissions tax rate to offset changes in other energy tax provisions on the basis of periodic reviews of country tax systems, and progress on emissions reductions, by an independent agency like the International Monetary Fund. Measuring other energy tax provisions in terms of their equivalent tax (or subsidy) on $\mathrm{CO}_{2}$ would be contentious, however, because of opaque systems of tax preferences for energy investments, the possible role of energy taxes in correcting other externalities like local pollution and road congestion, and the 
possibility of nontax regulations that further penalize or subsidize energy (e.g., fuel economy and renewable portfolio standards, energy price regulations). On the other hand, most countries have established tax ministries that would be able to implement a new tax on (the carbon content of) fossil fuels. In contrast, many developing countries may lack the capacity to enforce permit requirements and property rights due to weak environmental agencies and judicial institutions.

Finally, although not incorporated in most energy-climate models, the forest sector appears to offer some of the least expensive opportunities for cutting back $\mathrm{CO}_{2}$ emissions. For example, under a $550 \mathrm{ppm} \mathrm{CO}_{2}$ stabilization target, Tavoni et al. (2007) estimate that unrestricted use of forest sinks can contribute one-third of total abatement by 2050, and thereby decrease the required price on $\mathrm{CO}_{2}$ emissions by around 40 percent. This is mainly achieved through avoided deforestation in tropical forests, though according to Tavoni et al. (2007) it could be sustained in the second half of the century through aforestation and enhanced forest management. Emissions credits for slowed deforestation were not permitted under the 1997 Kyoto framework, but since then analysts have become somewhat more optimistic about the feasibility of integrating deforestation into an international emissions control regime, despite the practical challenges noted above (e.g. DeFries et al. 2006). However, national programs have so far limited the use of these offsets, and broad participation among major tropical forest regions in any agreement would be critical to avoid the risk of serious emissions leakage.

\subsection{Summary}

A revenue-neutral $\mathrm{CO}_{2}$ tax has multiple desirable properties from an efficiency standpoint. Although allowances can be auctioned, and emissions price volatility contained, why implement a more elaborate cap-and-trade system if its purpose is to largely mimic the advantages of a tax? A likely answer is that political factors appear to favor the latter instrument (e.g., Goulder 2009). Emissions taxes, at least in the United States, appear to be highly unpopular, while cap-and-trade systems are popular among environmental advocates given their focus on binding emissions targets. They also have active supporters in the financial sector, who see cap-and-trade systems as an opportunity. But whichever instrument is chosen, getting the design details right is critical for cost-effectiveness, especially broad coverage of emissions, raising and efficiently using revenues, and containing price variability.

While most analysts agree that efficiency would be enhanced by complementing mitigation policies with additional policies to promote basic and applied research into emissionssaving technologies at government, university, and private institutions, the level of support and the specific instruments that should be employed are far less clear. And there is little consensus 
about the case for further policy intervention at the technology deployment stage - this depends on the specifics of the industries or processes involved and assumptions about consumer behavior that are in need of further study.

At an international level, the choice between cap-and-trade and emissions taxes is also nuanced. Either system can be globally cost-effective and accommodate transfers to developing countries. And while cap-and-trade systems are immune to the possibility of offsetting changes in the broader energy tax system, they may face larger implementation obstacles in developing countries. The biggest problem in transitioning away from the CDM toward an integrated global emissions trading system is the possibility of a large gap between the compensation that might be demanded by developing countries in exchange for their participation and the amount of compensation that developed countries are willing to provide - a gap that could be especially large under rapid atmospheric stabilization targets. Finally, integration of carbon forest sequestration into international emissions control agreements is potentially important for containing mitigation costs.

\section{Research Priorities}

While a great deal has been learned about climate policy design over the last couple of decades, much work remains to be done to cover many critical gaps in the literature.

Energy-climate models provide some rough bounds on the near-term emissions pricing trajectories and associated GDP losses implied by climate stabilization scenarios, and the range of uncertainty may narrow as more is learned about the costs of new technologies and behavioral responses to emissions pricing. Nonetheless, there are many research priorities in this area, such as trying to narrow disagreement over BAU emissions assumptions (e.g., through better population projections), improving the representation of endogenous technological change and prior policy distortions in the models, quantifying the benefits of major technological breakthroughs to guide R\&D efforts, and further exploring the cost and distributional implications of deviations from globally efficient emissions pricing.

Some of the biggest challenges facing climate economists are to develop and apply methodologies for valuing the wide array of market and nonmarket impacts across different regions, time periods, and scenarios for climate change (ecological, health, and extreme sea level impacts, in particular, are poorly understood). However, in terms of shedding more light on whether there is a solid economic basis for aggressive, as opposed to more moderate, near-term emissions pricing, the most critical issues in need of study appear to be the nature and magnitude 
of damage risks from extreme warming scenarios and the extent to which the possibility of future, midcourse corrections and the deployment of last-resort technologies in response to future learning lowers the near-term emissions price. More research on discounting might also be valuable, for example, exploring the implications for discounting of tax and other distortions in international capital markets.

On the design of domestic mitigation schemes, one topic badly in need of study, given the potentially large revenues from carbon policies, is the efficiency and distributional implications of the diverse array of options for revenue use. Additional research priorities include the design of practical, cost-effective provisions to address international emissions leakage and incorporate incentives for abatement of non- $\mathrm{CO}_{2} \mathrm{GHGs}$ and forest carbon sequestration.

As regards complementary technology policy, research is needed on both the appropriate level, and the relative efficiency, of alternative instruments to encourage technology breakthroughs as well as the amount and composition of basic energy R\&D. Empirical research (e.g., on consumer valuation of energy efficiency) is also needed to ascertain the extent of additional market failures that might justify additional regulations to raise energy efficiency or promote new technology deployment. From a positive research perspective, further work is also needed on the interactions, and possible redundancies, among increasingly prevalent climateand energy-related regulatory interventions (e.g., in the transportation sector this would include interactions between carbon policies, fuel taxes, fuel economy standards, low-carbon fuel standards, vehicle purchase subsidies, and subsidies and mandates for alternative fuels).

Finally, a critical issue at the international level is the design of rules for accession and graduated responsibilities for developing countries that are widely perceived as being fair, while at the same time minimizing deviations from cost-effective emissions pricing and finding an acceptable balance of transfers from developed to developing countries. 


\section{References}

Adams, R. M., C. Rosenzweig, R. M. Peart, J. T. Ritchie, B. A. McCarl, J. D. Glyer, R. B. Curry, J. W. Jones, K. J. Boote, and L. H. Allen Jr. 1990. Global Climate Change and US Agriculture. Nature 345 (6272): pp. 219-24.

Aldy, J.E., and R.N. Stavins (eds.). 2007. Architectures for Agreement: Addressing Global Climate Change in the Post-Kyoto World. Cambridge: Cambridge University Press.

Babiker, Mustafa H., and Thomas F. Rutherford. 2005. The Economic Effects of Border Measures in Subglobal Climate Agreements. The Energy Journal 26(4): 99-126.

Barrett, Scott. 2008. The Incredible Economics of Geoengineering. Environmental and Resource Economics 39: 45-54.

Baumol, William J., and Wallace E. Oates. 1971. The Use of Standards and Prices for Protection of the Environment. Swedish Journal of Economics 73: 42-54.

Bento, Antonio, and Mark Jacobsen. 2007. Ricardian Rents, Environmental Policy, and the "Double Dividend" Hypothesis. Journal of Environmental Economics and Management 53(1): 17-31.

Bosello, Francesco, Carlo Carraro, and Marzio Galeotti. 2001. The Double Dividend Issue: Modeling Strategies and Empirical Findings. Environment and Development Economics 6(1): 9-45.

Bovenberg, A. Lans, and Lawrence H. Goulder. 1997. Costs of Environmentally Motivated Taxes in the Presence of Other Taxes: General Equilibrium Analyses. National Tax Journal 50: 59-88.

Bovenberg, A. Lans, and Lawrence H. Goulder. 2001. Neutralizing the Adverse Industry Impacts of $\mathrm{CO} 2$ Abatement Policies: What Does It Cost? In Behavioral and Distributional Effects of Environmental Policy, edited by C. Carraro and G. Metcalf. Chicago: University of Chicago Press, 45-85.

Bovenberg, A. Lans, and Lawrence H. Goulder. 2002. Environmental Taxation and Regulation. In Handbook of Public Economics, edited by A. Auerbach and M. Feldstein. New York: North Holland.Burtraw, Dallas, Karen Palmer, Ranjit Bharvirkar, and Anthony Paul. 2001. The Effect of Allowance Allocation on the Cost of Carbon Emission Trading. Discussion paper 01-30. Washington, DC: Resources for the Future. 
Burtraw, D. and Palmer, K. 2008. Compensation Rules for Climate Policy in the Electricity Sector. Journal of Policy Analysis and Management 27(4):819-847.

Burtraw, Dallas, Karen Palmer, and Danny Kahn. 2009. A Symmetric Safety Valve. Discussion paper 09-06. Washington, DC: Resources for the Future.

Carraro, C. 2007. Incentives and Institutions: A Bottom-Up Approach to Climate Policy. In Architectures for Agreement: Addressing Global Climate Change in the Post-Kyoto World, edited by J.E. Aldy and R.N. Stavins. Cambridge: Cambridge University Press, $161-172$.

CEC (Commission of the European Communities). 2008. 2020 by 2020: Europe's Climate Change Opportunity. Communication from the Commission to the European Parliament, the Council, the European Economic and Social Committee, and the Committee of the Regions.

Clarke, Leon E., James A. Edmonds, Henry Jacoby, Hugh M. Pitcher, John M. Reilly, and Richard G. Richels. 2007. Scenarios of Greenhouse Gas Emissions and Atmospheric Concentrations. Washington, DC: U.S. Climate Change Science Program.

Clarke, Leon E., M. Wise, M. Placet, C. Izaurralde, J. Lurz, S. Kim, et al. 2006. Climate Change Mitigation: An Analysis of Advanced Technology Scenarios. Richland, WA: Pacific Northwest National Laboratory.

Cline, William R. 2007. Global Warming and Agriculture: Impact Estimates by Country. Washington, DC: Center for Global Development.

CRA International. 2008. Economic Analysis of the Lieberman-Warner Climate Security Act of 2007 Using CRA's MRN-NEEM Model. Summary of Findings, April 8. http://216.133.239.2/pdf/040808_crai_presentation.pdf.

Dales, J.H. 1968. Pollution, Property, and Prices. Toronto, Ontario: University of Toronto Press. DeFries, R., F. Achard, S. Brown, M. Herold, D. Murdiyarso, B. Schlamadinger, and C. de Souza Jr. 2006. Reducing Greenhouse Gas Emissions from Deforestation in Developing Countries: Considerations for Monitoring and Measuring. Rome: Global Terrestrial Observing System.

de la Chesnaye, F., and John Weyant (eds.). 2006. Multi-Greenhouse Gas Mitigation and Climate Policy. The Energy Journal, Special Issue. 
Dinan, Terry M., and Diane L. Rogers. 2002. Distributional Effects of Carbon Allowance Trading: How Government Decisions Determine Winners and Losers. National Tax Journal 55: 199-222.

Eber, Michael, and Alan J. Krupnick. 2009. Valuing Climate Damages. Unpublished manuscript. Washington, DC: Resources for the Future.

Edmonds, Jae, Leon Clarke, Joshua Lurz, and Marshall Wise. 2008. Stabilizing $\mathrm{CO}_{2}$ Concentrations with Incomplete International Cooperation. Climate Policy 8(4): 355376.

Edmonds, Jae, Joseph M. Roop, and Michael J. Scott. 2000. Technology and the Economics of Climate Change Policy. Arlington, VA: Pew Center on Global Climate Change.

EIA. 2008a. Energy Market and Economic Impacts of S. 2191, the Lieberman-Warner Climate Security Act of 2007. Report SR/OIAF/2008-01. Washington, DC: Energy Information Administration, U.S. Department of Energy.

EIA. 2008b. International Energy Outlook 2008. Washington, DC: Energy Information Administration, U.S. Department of Energy.

Ellerman, A. Denny. 2005. US Experience with Emissions Trading: Lessons for $\mathrm{CO}_{2}$. In Climate Policy and Emissions Trading After Kyoto, edited by Bernd Hansjugren. Cambridge, UK: Cambridge University Press.

EPA. 2008. EPA Analysis of the Lieberman-Warner Climate Security Act of 2008 (S. 2191). Washington, DC: Office of Air Programs, U.S. Environmental Protection Agency.

Fankhauser, Samuel. 1995. Valuing Climate Change: The Economics of the Greenhouse. London, UK: Earthscan Publications.

Fell, Harrison, Ian A. MacKenzie, and William A. Pizer. 2008. Prices versus Quantities versus Bankable Quantities. Discussion paper 08-32. Washington, DC: Resources for the Future.

Fischer, Carolyn. 2008. Emissions Pricing, Spillovers, and Public Investment in Environmentally Friendly Technologies. Energy Economics 30 (2): 487-502.

Fischer, Carolyn, and Alan K. Fox. 2007. Output-Based Allocation of Emissions Permits for Mitigating Tax and Trade Interactions. Land Economics. Forthcoming.

Fischer, Carolyn, and Alan K. Fox. 2009. Combining Rebates with Carbon Taxes: Optimal Strategies for Coping with Emissions Leakage and Tax Interactions. Discussion paper 0902. Washington, DC: Resources for the Future. 
Fischer, Carolyn, and Richard G. Newell. 2008. Environmental and Technology Policies for Climate Mitigation. Journal of Environmental Economics and Management 55(2): 142162.

Fischer, Carolyn, Ian W.H. Parry, and William A. Pizer. 2003. Instrument Choice for Environmental Protection When Technological Innovation is Endogenous. Journal of Environmental Economics and Management 45: 523-545.

Fischlin, A., G.F. Midgley, J. Price, R. Leemans, B. Gopal, C. Turley, M. Rounsevell, P. Dube, J. Tarazona, and A. Velichko. 2007. Ecosystems, Their Properties, Goods, and Services. In Climate Change 2007: Impacts, Adaptation and Vulnerability. Contribution of Working Group II to the Fourth Assessment Report of the Intergovernmental Panel on Climate Change, edited by M.L. Parry, O.F. Canziani, J.P. Palutikof, P.J. van der Linden, and C.E. Hanson. Cambridge, UK: Cambridge University Press, 211-72.

Fisher, Anthony C., and Urvashi Narain. 2003. Global Warming, Endogenous Risk, and Irreversibility. Environmental and Resource Economics 25: 395-416.

Frankel, Jeffrey A. 2009. An Elaborated Proposal for Global Climate Policy Architecture: Specific Formulas and Emission Targets for All Countries in All Decades. Discussion paper. Cambridge, MA: Harvard Project on International Climate Agreements, Harvard University.

Gillingham, Kenneth T., Richard G. Newell, and William A. Pizer. 2008. Modeling Endogenous Technological Change for Climate Policy Analysis. Energy Economics 30(6): 27342753.

Gillingham, Kenneth, Richard G. Newell, and Karen Palmer. 2009. Energy Efficiency Economics and Policy. RFF Discussion Paper 09-13, Resources for the Future, Washington, DC. Forthcoming in the Annual Review of Resource Economics.

Goulder, Lawrence H. 1995. Environmental Taxation and the "Double Dividend": A Reader's Guide. International Tax and Public Finance 2(2): 157-183.

Goulder, Lawrence H. 2009. Carbon Taxes versus Cap-and-Trade. Working paper. Stanford, CA: Department of Economics, Stanford University.

Goulder, Lawrence H., and Koshy Matthai. 2000. Optimal $\mathrm{CO}_{2}$ Abatement in the Presence of Induced Technological Change. Journal of Environmental Economics and Management 39: $1-38$. 
Goulder, Lawrence H., and Stephen H. Schneider. 1999. Induced Technological Change and the Attractiveness of $\mathrm{CO}_{2}$ Emissions Abatement Policies. Resource and Energy Economics 21: 211-253.

Goulder, Lawrence H., Ian W.H. Parry, Roberton C. Williams, and Dallas Burtraw. 1999. The Cost-Effectiveness of Alternative Instruments for Environmental Protection in a SecondBest Setting. Journal of Public Economics 72: 329-360.

Griliches, Zvi. 1992. The Search for R\&D Spillovers. Scandinavian Journal of Economics 94 (supplement): S29-S47.

Guiteras, Raymond. 2007. The Impact of Climate Change on Indian Agriculture. Working paper. Cambridge, MA: Department of Economics, Massachusetts Institute of Technology.

Gupta, S., D.A. Tirpak, N. Burger, J. Gupta, N. Höhne, A.I. Boncheva, G.M. Kanoan, C. Kolstad, J.A. Kruger, A. Michaelowa, S. Murase, J. Pershing, T. Saijo, and A. Sari. 2007. Policies, Instruments and Co-operative Arrangements. In Climate Change 2007: Mitigation. Contribution of Working Group III to the Fourth Assessment Report of the Intergovernmental Panel on Climate Change, edited by B. Metz, O.R. Davidson, P.R. Bosch, R. Dave, and L.A. Meyer. Cambridge, UK: Cambridge University Press.

Hall, Daniel. 2007. Mandatory Regulation of Nontraditional Greenhouse Gases: Policy Options for Industrial Process Emissions and Non- $\mathrm{CO}_{2}$ Gases. In Assessing U.S. Climate Policy Options, edited by Raymond Kopp and William A. Pizer. Washington, DC: Resources for the Future, 183-188.

Hanemann, Michael. 2008. Climate Change Policy: A View from California. Discussion paper. Berkeley, CA: Department of Agricultural and Resource Economics, University of California, Berkeley.

Hansen, James. 2007. Scientific Reticence and Sea Level Rise. Environmental Research Letters 2: $1-6$.

Harvey, L.D. Danny, and Huang Zhen. 1995. Evaluation of the Potential Impact of Methane Clathrate Destabilization on Future Global Warming. Journal of Geophysical Research 100(D2): 2905-2926.

Heal, Geoffrey. 2009. Climate Economics: A Meta-Review and Some Suggestions for Future Research. Review of Environmental Economics and Policy 3(1): 4-21. 
Ho, Mun, Richard D. Morgenstern, and Jhih-Shyang Shih. 2008. Impact of Carbon Price Policies on U.S. Industry. Discussion paper 08-37. Washington, DC: Resources for the Future.

Hoel, Michael, and Larry S. Karp. 2002. Taxes Versus Quotas for a Stock Pollutant. Resource and Energy Economics 24: 367-384.

IPCC. 2007. Climate Change 2007: The Physical Science Basis. Contribution of Working Group I to the Fourth Assessment Report of the Intergovernmental Panel on Climate Change. Cambridge, MA: Cambridge University Press.

Jacoby, Henry D., and A. Denny Ellerman. 2004. The Safety Valve and Climate Policy. Energy Policy 32(4): 481-491.

Jacoby, Henry D., Mustafa H. Babiker, Sergey Paltsev, and John M. Reilly. 2008. Sharing the Burden of GHG Reductions. Discussion paper. Cambridge, MA: Harvard Project on International Climate Agreements, Harvard University.

Jaffe, Adam B., Richard G. Newell, and Robert N. Stavins. 2003. Technological Change and the Environment. In Handbook of Environmental Economics (vol. 1), edited by K.G. Maler and J.R. Vincent. Amsterdam, Netherlands: Elsevier Science, 217-223.

Jaffe, Judson, and Robert N. Stavins. 2008. Linking a U.S. Cap-and-Trade System for Greenhouse Gas Emissions: Opportunities, Implications, and Challenges. Working paper 08-01. Washington, DC: AEI Center for Regulatory and Market Studies.

Jones, Charles I., and John C. Williams. 1998. Measuring the Social Return to R\&D. Quarterly Journal of Economics 113: 1119-35.

Jung, C., K. Krutilla, and R. Boyd. 1996. Incentives for Advanced Pollution Abatement Technology at the Industry Level: An Evaluation of Policy Alternatives. Journal of Environmental Economics and Management 30: 95-111.

Karp, Larry S., and Jiangfeng Zhang. 2005. Regulation of Stock Externalities with Correlated Abatement Costs. Environmental and Resource Economics 32: 273-300.

Keeler, Andrew G., and Alexander Thompson. 2008. Industrialized-Country Mitigation Policy and Resource Transfers to Developing Countries: Improving and Expanding Greenhouse Gas Offsets. Discussion paper. Cambridge, MA: Harvard Project on International Climate Agreements, Belfer Center, Harvard University.

Kling, Catherine L., and Jonathan Rubin. 1997. Bankable Permits for the Control of Environmental Pollution. Journal of Public Economics 64(1): 101-115. 
Kneese, Allen V., and Blair T. Bower. 1968. Managing Water Quality: Economics, Technology, Institutions. Baltimore, MD: Johns Hopkins Press.

Kolstad, Charles D. 1996a. Fundamental Irreversibilities in Stock Externalities. Journal of Public Economics 60: 221-233.

Kolstad, Charles D. 1996b. Learning and Stock Effects in Environmental Regulation: The Case of Greenhouse Gas Emissions. Journal of Environmental Economics and Management 31: $1-18$.

Lind, R. 1982. A Primer on the Major Issues Relating to the Discount Rate for Evaluating National Energy Options. In Discounting for Time and Risk in Energy Policy, edited by R. Lind. Washington, DC: Resources for the Future.

Mansfield, Edwin. 1985. How Fast Does New Industrial Technology Leak Out? Journal of Industrial Economics 34: 217-33.

McGrattan, E., and E.C. Prescott. 2003. Average Debt and Equity Returns: Puzzling? The American Economic Review 93(2): 392-397.

McMichael, Anthony J., Diarmid Campbell-Lendrum, Sari Kovats, Sally Edwards, Paul Wilkinson, Theresa Wilson, Robert Nicholls, Simon Hales, Frank Tanser, David Le Sueur, Michael Schlesinger, and Natasha Andronova. 2004. "Global Climate Change," in Comparative Quantification Of Health Risks: Global and Regional Burden of Disease Attributable to Selected Major Risk Factors. Majid Ezzati, Alan D. Lopez, Anthony Rodgers and Christopher J. L. Murray eds. Geneva: World Health Organization.

Mendelsohn, Robert and James Neumann. 1999. The Impacts of Climate Change on the American Economy. Cambridge, UK: Cambridge University Press.

Mendelsohn, Robert, William D. Nordhaus, and D. Shaw. 1994. The Impact of Global Warming on Agriculture: A Ricardian Analysis. American Economic Review 84(4): 753-71.

Mendelsohn, Robert, A. Dinar, and A. Sanghi. 2001. The Effect of Development on the Climate Sensitivity of Agriculture. Environment and Development Economics 6(1): 85-101.

Mendelsohn, Robert and L. Williams. 2004. Comparing Forecasts of the Global Impacts of Climate Change. Mitigation and Adaptation Strategies for Global Change 9: 315-333

Mendelsohn, Robert and L. Williams. 2007. Dynamic Forecasts of the Sectoral Impacts of Climate Change. In Michael E. Schlesinger et al. (eds)., Human-Induced Climate Change: An Interdisciplinary Assessment, Cambridge University Press, Cambridge, MA. 
Metcalf, Gilbert E. 2009. Designing a Carbon Tax to Reduce U.S. Greenhouse Gas Emissions. Review of Environmental Economics and Policy 3(1): 63-83.

Milliman, S.R., and R. Prince. 1989. Firm Incentives to Promote Technological Change in Pollution Control. Journal of Environmental Economics and Management 17: 24ர̃-265.

Montgomery, W. David. 1972. Markets in Licenses and Efficient Pollution Control Programs. Journal of Economic Theory 5: 395-418.

Mueller, Benito, Niklos Hoehne, and Christian Ellerman, 2007. Differentiating (Historic) Responsibilities for Climate Change. www.oxfordclimatepolicy.org

Murray, Brian C., Bruce A. McCarl, and Heng-chi Lee. 2004. Estimating Leakage from Forest Carbon Sequestration Programs. Land Economics 80(1):109-124.

Murray, Brian C., Richard G. Newell, and William A. Pizer. 2009. Balancing Cost and Emissions Certainty: An Allowance Reserve for Cap-and-Trade. Review of Environmental Economics and Policy 3(1): 84-103.

Newbold, Stephen C., and Adam Daigneault. 2008. Climate Response Uncertainty and the Expected Benefits of Greenhouse Gas Emission Reductions. Unpublished manuscript. Washington, DC: U.S. Environmental Protection Agency.

Newell, Richard G. 2008. A U.S. Innovation Strategy for Climate Change Mitigation. Washington, DC: Brookings Institution.

Newell, R.G. and W.A. Pizer. 2003. Discounting the distant future: How much do uncertain rates increase valuations? Journal of Environmental Economics and Management 46(1):52-71.

Newell, Richard G., and William A. Pizer. 2003. Regulating Stock Externalities Under Uncertainty. Journal of Environmental Economics and Management 45: 416-432.

Newell, Richard G., William A. Pizer and Jiangfeng Zhang. 2005. Managing Permit Markets to Stabilize Prices, Environment and Resource Economics 31(2): 133-157

Ng, Wei-Shiuen and R. Mendelsohn, 2005. The Impact of Sea Level Rise on Singapore. Environment and Development Economics 10: 201-15.

Nicholls, Robert J., Richard S.J. Tol, and Athanasios T. Vafeidis. 2008. Global Estimates of the Impact of a Collapse of the West Antarctic Ice Sheet: An Application of FUND. Climatic Change 91(1-2): 171-191. 
Nordhaus, William D. 1991. To Slow or Not to Slow: The Economics of the Greenhouse Effect. Economic Journal 101 (407): 920-37.

Nordhaus, William D. 2002. Modeling Induced Innovation in Climate-Change Policy. In Technological Change and the Environment, edited by Arnulf Grubler, Nebojsa Nakicenovic, and William Nordhaus. Washington, DC: Resources for the Future, 182209.

Nordhaus, William D. 2007. A Review of the Stern Review on the Economics of Climate Change. Journal of Economic Literature 45(3): 686-702.

Nordhaus, William D. 2008. A Question of Balance: Weighing the Options on Global Warming Policies. New Haven, CT: Yale University Press.

Nordhaus, William D., and J. Boyer. 2000. Warming the World: Economic Models of Global Warming. Cambridge, MA: MIT Press.

Olsthoorn, Alexander A., Peter E. van der Werff, Laurens M. Bouwer, and David Huitema. 2008. Neo-Atlantis: The Netherlands Under a 5-m Sea Level Rise. Climatic Change 9(12): $103-122$.

Paltsev, Sergey, John M. Reilly, Henry D. Jacoby, Angelo C. Gurgel, Gilbert E. Metcalf, Andrei P. Sokolov, and Jennifer F. Holak. 2007. Assessment of U.S. Cap-and-Trade Proposals. Report No. 146. Cambridge, MA: MIT Joint Program on the Science and Policy of Global Climate Change.

Parry, Ian W.H. 2005. Fiscal Interactions and the Costs of Pollution Control from Electricity. RAND Journal of Economics 36: 849-869.

Parry, Ian W.H., and Antonio M. Bento. 2000. Tax Deductions, Environmental Policy, and the "Double Dividend" Hypothesis. Journal of Environmental Economics and Management 39: 67-96.

Parry, Ian W.H., William A. Pizer, and Carolyn Fischer. 2003. How Large Are the Welfare Gains from Technological Innovation Induced by Environmental Policies? Journal of Regulatory Economics 23: 237-255.

Pearce, David W. 2005. The Social Cost of Carbon. In Climate Change Policy, edited by Dieter Helm. Oxford, UK: Oxford University Press. 
Peck, S.C., and Y.H. Wan. 1996. Analytic Solutions of Simple Greenhouse Gas Emission Models. In Economics of Atmospheric Pollution, edited by E.C. Van Ierland and K. Gorka. New York: Springer Verlag, Ch. 6.

Pindyck, Robert S. 2007. Uncertainty in Environmental Economics. Review of Environmental Economics and Policy: 1: 45-65.

Pindyck, Robert S. 2008. Uncertainty, Extreme Outcomes, and Climate Change Policy. Paper presented at the National Bureau of Economic Research Summer Institute, Environmental and Energy Economics. July 2008, Cambridge, MA.

Pizer, William A. 2003. Combining Price and Quantity Controls to Mitigate Global Climate Change. Journal of Public Economics 85: 409-434.

Pizer, William A. 2007. Practical Global Climate Policy. In Architectures for Agreement: Addressing Global Climate Change in the Post-Kyoto World, edited by J.E. Aldy and R.N. Stavins. Cambridge: Cambridge University Press, 280-314.

Popp, David. 2006. Innovation in Climate Policy Models: Implementing Lessons from the Economics of R\&D. Energy Economics 28: 596-609.

Popp, David, Richard G. Newell, and Adam B. Jaffe. 2009. Energy, the Environment, and Technological Change. NBER Working Paper 14832, Cambridge, MA. Forthcoming in the Handbook of Economics of Technical Change. North Holland.

Reilly, J. M et al. 2001. Agriculture: The Potential Consequences of Climate Variability and Change for the United States. New York: Cambridge University Press.

Roberts, M.J., and M. Spence. 1976. Effluent Charges and Licenses Under Uncertainty. Journal of Public Economics 5(3-4): 193-208.

Rosendahl, Knut Einar. 2008. Incentives and Prices in an Emissions Trading Scheme with Updating. Journal of Environmental Economics and Management 56: 69-82.

Rosendahl, Knut Einar, and Jon Strand. 2008. Simple Model Frameworks for Explaining Inefficiency of CDM. Unpublished manuscript. Washington, DC: World Bank.

Schelling, Thomas. 2007. Epilogue: Architectures for Agreement. In Architectures for Agreement: Addressing Global Climate Change in the Post-Kyoto World, edited by J.E. Aldy and R.N. Stavins. Cambridge: Cambridge University Press, 343-349. 
Schlenker, Wolfram, W. Michael Hanemann, and Anthony C. Fisher. 2005. Will U.S.

Agriculture Really Benefit from Global Warming? Accounting for Irrigation in the Hedonic Approach. American Economic Review 95(1): 395-406.

Shih, Jhih-Shyang, Dallas Burtraw, Karen Palmer, and Juha Siikamäki. 2006. Air Emissions of Ammonia and Methane from Livestock Operations. Discussion paper 06-11. Washington, DC: Resources for the Future.

Sijm, J., K. Neuhoff, and Y. Chen. 2006. $\mathrm{CO}_{2}$ Cost Pass-Through and Windfall Profits in the Power Sector. Climate Policy 6(1): 49-72.

Smith, Anne E., Martin E. Ross, and W. David Montgomery. 2002. Implications of Trading Implementation Design for Equity-Efficiency Tradeoffs in Carbon Permit Allocations. Working paper. Washington, DC: Charles River Associates.

Sohngen, Brent and S. Brown. 2004. Measuring Leakage from Carbon Projects in Open Economies: A Stop Timber Harvesting Project as a Case Study. Canadian Journal of Forest Research 34: 829-839.

Sohngen, Brent, Robert Mendelsohn, and Roger Sedjo, 2001. A Global Model of Climate Change Impacts on Timber Markets. Journal of Agricultural and Resource Economics 26 (2): $326-43$.

Stavins, Robert N. 1995. Transactions Costs and Tradable Permits. Journal of Environmental Management and Policy 29: 133-148.

Stavins, R.N. 1996. Correlated Uncertainty and Policy Instrument Choice. Journal of Environmental Economics and Management 30: 218-232.

Stavins, R.N. 2007. A U.S. Cap-and-Trade Proposal to Address Global Climate Change. Discussion paper 2007-13. Washington, DC: Brookings Institution.

Stavins, Robert N., and Kenneth Richards. 2005. The Cost of U.S. Forest-Based Carbon Sequestration. Report. Arlington, VA: Pew Center on Global Climate Change.

Stern, Nicholas. 2007. The Economics of Climate Change: The Stern Review. Cambridge, UK: Cambridge University Press.

Sterner, Thomas, and U. Martin Persson. 2008. An Even Sterner Review: Introducing Relative Prices into the Discounting Debate. Review of Environmental Economics and Policy 2(1): $61-76$. 
Tavoni, Massimo, Brent Sohngen, and Valentina Bosetti. 2007. Forestry and the Carbon Market Response to Stabilize Climate. Energy Policy 35: 5346-5353.

Tol, Richard S. J. 1995. The Damage Costs of Climate Change: Toward More Comprehensive Calculations. Environmental and Resource Economics, 5(4): 353-74.

Tol, Richard S. J. 2002. Estimates of the Damage Costs of Climate Change. Part 1: Benchmark Estimates. Environmental and Resource Economics 21(1): 47-73.

Tol, Richard S. J. 2009. The Economic Effects of Climate Change. Journal of Economic Perspectives. Forthcoming.

van Benthem, Arthur, Kenneth Gillingham, and James Sweeney. 2008. Learning-by-Doing and the Optimal Solar Policy in California. The Energy Journal 29(3): 131-151.

Victor, David. 2007. Fragmented Carbon Markets and Reluctant Nations: Implications for the Design of Effective Architectures. In Architectures for Agreement: Addressing Global Climate Change in the Post-Kyoto World, edited by J.E. Aldy and R.N. Stavins. Cambridge: Cambridge University Press, 133-160.

Victor, David G. 2008. On the Regulation of GeoEngineering. Oxford Review of Economic Policy 24(2): 322-336.

Weitzman, M. 1974. Prices vs. Quantities. Review of Economic Studies 41(4): 477-491.

Weitzman, Martin. 1998. Why the Far-Distant Future Should be Discounted at its Lowest Possible Rate. Journal of Environmental Economics and Management 36: 201-208.

Weitzman, Martin, L. 2009a. On Modeling and Interpreting the Economics of Catastrophic Climate Change. Review of Economics and Statistics 91(1): 1-19.

Weitzman, Martin, L. 2009b. Reactions to the Nordhaus Critique. Discussion paper. Cambridge, MA: Department of Economics, Harvard University.

Wright, Brian D. 1983. The Economics of Invention Incentives: Patents, Prizes, and Research Contracts. American Economic Review 73(4): 691-707.

Yohe, Gary W. 1978. Towards a General Comparison of Price Controls and Quantity Controls Under Uncertainty. The Review of Economic Studies 45(2): 229-38.

Yohe, G., 2000. Assessing the Role of Adaptation in Evaluating Vulnerability to Climate Change. Climatic Change 46(3): 371-90. 
Yohe, Gary, and Richard S.J. Tol. 2009. Precaution and a Dismal Theorem: Implications for Climate Policy and Climate Research. In Risk Management in Commodity Markets, edited by H. Geman. New York: Wiley Press. Forthcoming.

\section{Tables and Figures}

\section{Box 1. Valuation of Noncatastrophic Climate Damages \\ (for Warming of $2.5^{\circ} \mathrm{C}$ or Thereabouts Occurring Around 2100)}

Agriculture. Estimates of consumer and producer surplus losses in agricultural markets from predicted changes in regional temperature and precipitation use evidence on crop and climate sensitivity from laboratory experiments and on the sensitivity of land values or farm performance to climate variables from regression analyses (e.g., Adams et al. 1990; Reilly et al. 2001; Mendelsohn et al. 1994). Laboratory studies can control for confounding factors like soil quality and the fertilizing effect of higher $\mathrm{CO}_{2}$ concentrations, while regression analyses account for farm-level adaptation (e.g., changes in crop variety and planting and harvesting dates). Worldwide agricultural impacts are built up by using extrapolations from U.S. studies, adjusting for differences in local agricultural composition and climate, and, more recently, country-specific evidence that captures local factors like adaptive capability. Overall, worldwide agricultural impacts are relatively modest, anything from a net gain of about 0.1 percent of GDP to a net loss of about 0.20 percent (Eber and Krupnick 2009). Estimates are not independent, as studies often draw from the same sources and from each other. Studies show a pattern of gains in high latitude and temperate regions (like Russia), where current temperatures are below optimum levels for crop growth, counteracting damages in tropical regions, where current temperatures are already higher than optimal. For example, studies suggest that agricultural damages for India would be disproportionately large (Mendelsohn et al. 2001; Guiteras 2007; Cline 2007).

Sea level. The annualized costs of future global sea level rises, due to thermal expansion and melting of sea ice, have been estimated by combining projections of which coastal regions will be protected with engineering data on the costs of dikes, sea walls, beach replenishment, etc., as well as losses from abandoned or degraded property in unprotected areas. Some studies assume efficient behavior by local policymakers in their choice of which areas to protect and at what time, while others assume all currently developed areas will be protected (Yohe 2000). Nordhaus (2008) also includes an estimate of property losses from increased storm intensity due to greater wind speed and waves coming off a higher water level; whether storms will also become more frequent in future with more humid air is unsettled in the literature (IPCC 2007). Worldwide impacts have been extrapolated from U.S. evidence, adjusting for the fraction of local land area in close proximity to the coast, though recently there have been some local studies that account for the slope and elevation of coastal land and prospective population growth (e.g., $\mathrm{Ng}$ and Mendelsohn 2005 on Singapore). Overall, estimates are relatively modest; for example, they amount to 0.32 of world GDP in Nordhaus (2008).

These estimates are based on sea level rises of around $25-60 \mathrm{~cm}$ over the next century, as projected by the IPCC (2007). However, some scientists project that sea levels could increase by several meters by 2100 
due, in particular, to melting of the West Antarctic Ice Sheet (e.g., Hansen 2007). This would have major impacts on New York, Boston, Miami, London, Tokyo, Bangladesh, the whole of the Netherlands, and so on, and would completely inundate several small island states. Based on extrapolations from sea level protection costs in Holland, the global costs of this more extreme sea level rise may be at least an order of magnitude or more greater than for a moderate sea level rise, especially if coastal protection cannot be constructed expeditiously (Nicholls et al. 2008; Olsthoorn et al. 2008). Another possibility is that warming may cause changes in ocean circulation patterns. However, IPCC (2007) projects that warming from climate change will dominate any cooling effect on Europe from a weaker Gulf Stream.

Other market sectors. Less attention has been paid to other market sectors, though studies suggest their impacts are relatively minor. With most forests along the increasing part of the inverted-U relation between forest productivity and temperature, Sohngen et al. (2001) find positive overall impacts from warming on global timber markets. Most studies find a net loss for the energy sector, as increased costs for space cooling dominate savings in space heating (e.g., Mendelsohn and Neumann 1999). Impacts on water availability also tend to be negative, as increased evaporation reduces freshwater supplies, and the value of these losses is compounded with greater demand for irrigation (Mendelsohn and Williams 2007).

Health. As regards nonmarket effects, there have been some attempts to quantify future health damages. For example, using statistical evidence on climate and disease, Nordhaus and Boyer (2000) put health risks from the possible spread of vector-borne diseases like malaria at 0.10 percent of world GDP. Broader health risks are even more speculative. According to McMichael et al. (2004), there were 166,000 excess deaths worldwide in 2000 from climate change to date. Of these, "only" 16 percent were from malaria, 46 percent reflected greater malnutrition due to food shortages, another 28 percent reflected more diarrhea cases as droughts reduced safe drinking water supplies and concentrated contaminants, while 7 percent were from temperature extremes (most in Southeast Asia). However, malnutrition projections are extremely sensitive to assumptions about whether, over the next century, currently vulnerable regions develop, become more integrated into global food markets, and are able to adopt hardier crops. And increased incidence of water-borne illness may, or may not, be counteracted by future development and adoption of water purification systems. Monetizing mortality effects is also contentious as there are very few direct estimates of the value of a statistical life for poor countries.

Ecosystems. All aspects of future climate change are potential stressors to natural systems. Combining projections of ecosystems at risk from climate change with evidence on the medicinal value of plants and willingness to pay for species and habitat preservation, Fankhauser (1995) and Tol (1995) put the value of ecosystem loss in 2100 at 0.21 percent and 0.13 percent of world GDP, respectively. Nordhaus and Boyer (2000) put the combined risks to natural ecosystems and climate-sensitive human settlements at 0.17 percent of world GDP in 2100, assuming the capital value of vulnerable systems is 5-25 percent of regional output, and an annual willingness to pay equal to 1 percent of capital value. These estimates are highly speculative, given that very little is known about ecological impacts and how people value large scale (as opposed to marginal) ecosystem loss. 
TABLE 1. LEAST-COST POLICIES TO STABILIZE GLOBAL CLIMATE

\begin{tabular}{|c|c|c|c|c|c|c|c|c|c|}
\hline & \multicolumn{3}{|c|}{2025} & \multicolumn{3}{|c|}{2050} & \multicolumn{3}{|c|}{2100} \\
\hline $\operatorname{cCSP}^{a}$ & MERGE & MiniCAM & 1 IGSM & MERGE & MiniCAM & IGSM & MERGE & MiniCAM & 1 IGSM \\
\hline \multicolumn{10}{|l|}{$\mathrm{CO}_{2}$ concentration, $\mathrm{ppm}^{\mathrm{b}}$} \\
\hline Reference & 422 & 430 & 436 & 485 & 507 & 544 & 711 & 746 & 875 \\
\hline $450 \mathrm{CO}_{2}$ stabilization & 412 & 416 & 408 & 434 & 440 & 430 & 426 & 456 & 451 \\
\hline $550 \mathrm{CO}_{2}$ stabilization & 421 & 427 & 421 & 478 & 490 & 472 & 535 & 562 & 526 \\
\hline \multicolumn{10}{|c|}{ Global $\mathrm{CO}_{2}$ emissions, relative to 2000} \\
\hline Reference & 1.27 & 1.46 & 1.70 & 1.59 & 1.98 & 2.59 & 3.42 & 3.21 & 3.45 \\
\hline $450 \mathrm{CO}_{2}$ stabilization & 0.92 & 0.97 & 0.86 & 0.53 & 0.57 & 0.64 & 0.24 & 0.39 & 0.55 \\
\hline $550 \mathrm{CO}_{2}$ stabilization & 1.25 & 1.35 & 1.22 & 1.32 & 1.56 & 1.20 & 0.79 & 0.71 & 0.81 \\
\hline \multicolumn{10}{|c|}{ US $\mathrm{CO}_{2}$ emissions, relative to 2000} \\
\hline Reference & 1.25 & 1.10 & 1.40 & 1.27 & 1.20 & 2.00 & 1.63 & 1.34 & 2.93 \\
\hline $450 \mathrm{CO}_{2}$ stabilization & 0.79 & 0.83 & 0.88 & 0.42 & 0.43 & 0.54 & 0.02 & 0.27 & 0.40 \\
\hline $550 \mathrm{CO}_{2}$ stabilization & 1.24 & 1.05 & 1.04 & 1.02 & 0.98 & 1.13 & 0.29 & 0.37 & 0.59 \\
\hline \multicolumn{10}{|l|}{$\mathrm{CO}_{2}$ price, $\$ /$ ton $^{\mathrm{c}}$} \\
\hline $450 \mathrm{CO}_{2}$ stabilization & 41 & 36 & 88 & 157 & 127 & 230 & 166 & 173 & 1651 \\
\hline $550 \mathrm{CO}_{2}$ stabilization & 3 & 6 & 26 & 10 & 19 & 67 & 127 & 115 & 475 \\
\hline \multicolumn{10}{|c|}{$\%$ reduction in world GDP } \\
\hline $450 \mathrm{CO}_{2}$ stabilization & 0.8 & 0.5 & 2.6 & 1.8 & 1.6 & 5.4 & 1.4 & 1.4 & 16.1 \\
\hline $550 \mathrm{CO}_{2}$ stabilization & 0.0 & 0.0 & 0.7 & 0.2 & 0.2 & 1.8 & 0.7 & 1.0 & 6.8 \\
\hline EMF-21 ${ }^{\mathrm{e}}$ & lower end & median & upper end & lower end & median & upper end & lower end & d median & upper end \\
\hline \multicolumn{10}{|c|}{ Global $\mathrm{CO}_{2}$ emissions, relative to 2000} \\
\hline Reference & 1.33 & 1.48 & 1.64 & 1.64 & 1.88 & 2.23 & 2.11 & 2.93 & 3.52 \\
\hline $550 \mathrm{CO}_{2}$ stabilization & 1.17 & 1.25 & 1.41 & 1.13 & 1.25 & 1.41 & 0.66 & 0.90 & 1.25 \\
\hline \multicolumn{10}{|c|}{ US $\mathrm{CO}_{2}$ emissions, relative to 2000} \\
\hline Reference & 1.19 & 1.26 & 1.38 & 1.31 & 1.65 & 1.97 & 0.95 & 1.85 & 2.29 \\
\hline $550 \mathrm{CO}_{2}$ stabilization & 1.05 & 1.14 & 1.22 & 0.76 & 1.02 & 1.26 & 0.36 & 0.53 & 1.05 \\
\hline \multicolumn{10}{|l|}{$\mathrm{CO}_{2}$ price, $\$ /$ ton $^{\mathrm{c}}$} \\
\hline $550 \mathrm{CO}_{2}$ stabilization & 3 & 13 & 21 & 12 & 33 & 99 & 31 & 92 & 166 \\
\hline \multicolumn{10}{|c|}{$\%$ reduction in world GDP ${ }^{d}$} \\
\hline $550 \mathrm{CO}_{2}$ stabilization & 0.1 & 0.1 & 0.8 & 0.2 & 0.6 & 3.1 & 0.3 & 5.1 & 8.2 \\
\hline
\end{tabular}

Notes

${ }^{a}$ Clarke et al. (2007).

${ }^{\mathrm{b}}$ The models stabilize concentrations of all GHGs, rather than $\mathrm{CO}_{2}$ alone (i.e., the $\mathrm{CO}_{2}$ equivalent concentration level is higher than the $\mathrm{CO}_{2}$ concentration). Moreover, actual $\mathrm{CO}_{2}$ concentrations may exceed the approximate targets of 450 and $550 \mathrm{ppm}$.

'In year 2000 dollars or thereabouts.

${ }^{\mathrm{d}} \mathrm{GDP}$ losses are not broken out by region in the models. Losses include those from pricing $\mathrm{CO}_{2}$ and other $\mathrm{GHG}$ on an equivalent basis. The figures do not account for the benefits of reduced climate change.

ede la Chesnaye and Weyant (2006). Results for EMF-21 are from 16 models for $\mathrm{CO}_{2}$ prices and 12 models for GDP. Lower and upper ends correspond to lower and upper two-thirds of model results. Atmospheric $\mathrm{CO}_{2}$ concentrations are not reported. 
Figure 1. Steady State Warming Above Preindustrial Temperatures from Stabilization at Different GHG Concentrations

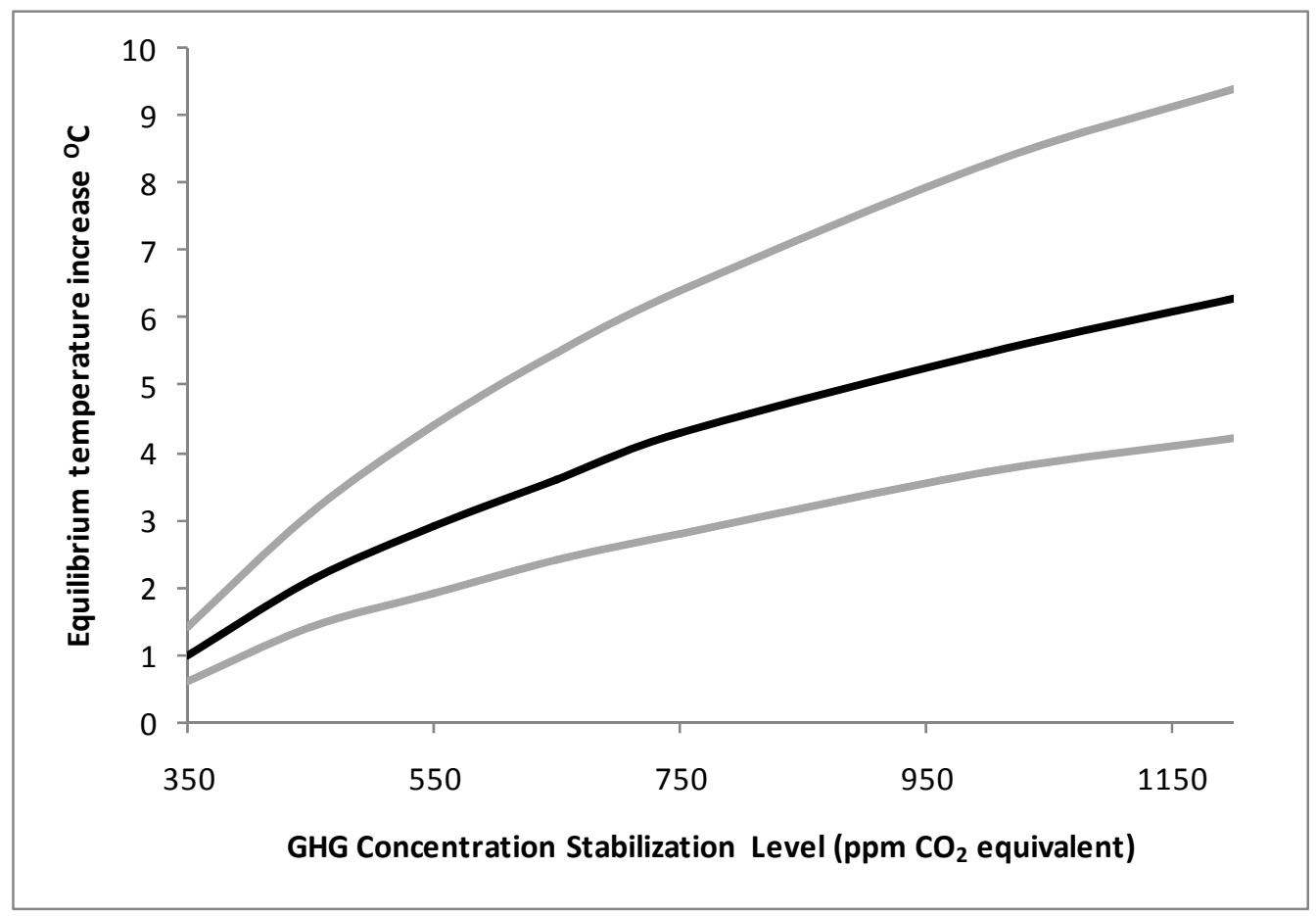

Source: IPCC (2007), Table 10.8.

Note: The black curve indicates the central case projection and the grey curves indicate the 66 percent confidence interval. 
Figure 2. Selected Estimates of Contemporaneous World GDP Damages from Global Warming Occurring Around 2100

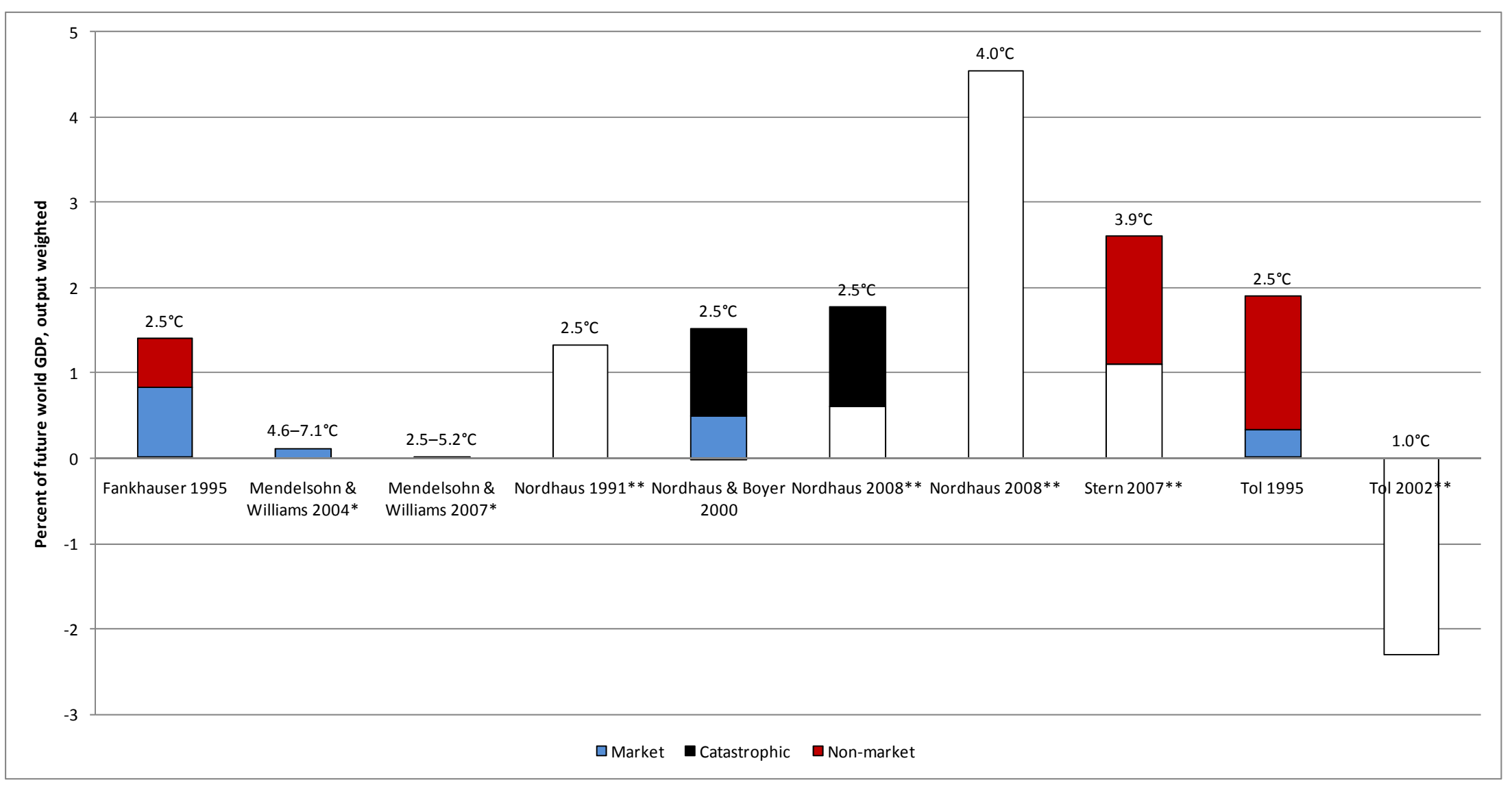

* Only market damages were estimated in these studies. And the above figure is the midpoint of a range of damage estimates.

** Damage categories are not precisely de-lineated in these studies. 